DOI: https://doi.org/10.24164/prosiding.v3i1.11

\title{
SIMBOL-SIMBOL PENUTUR AUSTRONESIA DI ASIA TENGGARA: STUDI KASUS DI KEPULAUAN MALUKU
}

\author{
Austronesia Symbol in Southeast Asia: Case Study in Moluccas Archipelago
}

\author{
Lucas Wattimena \\ Balai Arkeologi Maluku \\ Jalan Namalatu-Latuhalat, Kec. Nusaniwe Kota Ambon, \\ Maluku-Indonesia 97118 \\ E-mail: lucas.wattimena@yahoo.com
}

\begin{abstract}
This paper provides an overview of how the forms of symbols that are found in boat of Austranesian speakers in the Moluccas Archipelago. The boat discussed in this paper is a type of boat and boat made from wooden planks. The forms of symbols contained in boat of Austronesian spekers, among others, are classified in the category of fertility symbols, human and female symbols, flora and fauna symbols, life cycle symbols (birth, adult and death), sex symbols (reproductive organs), kinship symbols, geometric symbols, stripes and circles.
\end{abstract}

Keywords: symbol, boat, austronesia speaking, Moluccas Archipelago, Southeast Asia.

\section{AbSTRAK}

Makalah ini memberikan gambaran tentang bagaimana bentuk-bentuk simbol yang terdapat di perahu penutur austronesia di Kepulauan Maluku. Perahu yang dibahas dalam makalah ini adalah jenis perahu bercadik dan perahu dari susunan papan kayu. Bentuk2 simbol yang terdapat di perahu penutur Austronesia antara lain diklasifikasian dalam kategori simbol kesuburan, simbol manusia perempuan dan laki-laki, simbol flora dan fauna, simbol siklus hidup (lahir, dewasa dan kematian), simbol seks (alat reproduksi), simbol kekerabatan, simbol geometris, bergaris dan lingkaran.

Kata kunci : simbol, perahu, penutur Austronesia, kepulauan Maluku, Asia Tenggara.

\section{PENDAHULUAN}

Tndonesia sebagai salah satu Negara Kepulauan di Asia Tenggara yang berada di antara Samudra Hindia dan Pasifik serta Benua Australia mempunyai keragaman manusia dan budaya yang tersebar diseantero wilayah dari ujung Sumatra sampai Papua. Indonesia di Kawasan Asia Tenggara terdiri dari Kawasan pulau-pulau besar, yaitu Pulau Kalimantan, Jawa, Sulawesi, Sumatra dan Papua. dan gugusan pulau-pulau kecil, yaitu Kepulauan Maluku, Nusa Tenggara
Timur, Nusa Tenggara Barat, Bali. Kondisi tersebut membuat Indonesia terkenal dengan dunia kemaritimannya. Geografis Indonesia terdiri dari lautan dan daratan serta pulaupulau besar dan kecil membentang secara horizontal dan vertikal pada poros dunia (Harkantingsih, 2014) (Ririmasse, 2007) (Harkantingsih, 2014; Daud A Tanudirjo, 2001) (M. N. Ririmasse, 2016) (Oktaviana et al., 2018). (Hersanti et al., 2008) (Wibisono, 2014). Laut adalah bagian tersistim dari dinamika perkembangan manusia budaya 
di Indonesia dan Asia Tenggara, karena laut memegang peranan penting, dalam konteks laut sebagai identitas, laut sebagai beranda depan, laut sebagai pusaka Bersama, laut sebagai pemersatu bangsa, laut sebagai Kawasan persaingan kebudayaan dan kontak kebudayaan (M. N. Ririmasse, 2016) (Simanjuntak, 2011) (Tanudirdjo, 2011) (Wattimena, 2016). (Lapian, 2008). Konteks laut inheren dengan perahu, manusia dan pendukungnya (tradisi) yang membentuk kesatuan sistimatis yang disebut kemaritiman. Kesatuan sistim ini membentuk mekanismemekanisme yang tersalurkan lewat salah satu media yaitu simbol. Makalah ini membahas tentang simbol-simbol yang terdapat pada perahu Orang Indonesia, khususnya Orang Maluku.

Alasan penting kenapa dalam makalah ini membahasa tentang perahu Orang Maluku, karena 1) kondisi geografis Kepulauan Maluku 90\% lautan dan pulaupulau kecil, sehingga perahu menjadi factor penting dalam sistim kemaritiman. 2) Ekspresi kebudayaan plural dapat dilihat pada simbol-simbol yang terdapat di perahu Orang Maluku. Jenis perahu dalam pembahasan makalah ini antara lain jenis susunan papan kayu dan perahu bercadik. Jenis perahu ini dapat ditemukan diseantero belahan dunia (Horridge, 2015) (Lapian, 2008) (Oppenheimer \& Richards, 2001) (Bellwood et al., 2006) (Pham, 2016) (Mahdi, 1999). Perahu adalah sebuah alat transportasi di seluruh dunia yang berperan penting dalam lintas regional maupun universal. Keberagaman perlintasan tersebut membuat perahu memiliki simbol identitas dalam pencaturan kompleksitas kebudayaan di Nusantara. Austronesia sebagai salah satu pencaturan dimaksud dengan kepandaian teknologi pelayaran mengarungi laut. Perahu oleh Horst (Liebner, 2005) setidaknya memiliki bagian layar untuk dapat mengarungi laut dengan segala kondisi cuaca dan manuver atau pergerakan diatas laut yang dapat dilakukan.

Lokasi pembahasan dalam tulisan ini meliputi wilayah kerja Balai Arkeologi Maluku yaitu Provinsi Maluku dan Maluku Utara yang berada di timur Indonesia dalam gugusan kepulauan Wallacea. Gugusan Wallacea adalah gugusan pulau-pulau kecil dan besar yang membentang vertikal horizontal menghubungkan wilayah Sunda dan Sahul. Pertimbangan lokasi penelitian memiliki beberapa alasan mendasar yaitu: 1) isu perahu sebagai sebuah simbol menjadi kosmos penting dalam tatanan kependudukan masyarakat Maluku dan Maluku Utara. 2) informasi simbol pada perahu di Maluku dan Maluku Utara masih minim dibicarakan dalam konteks persebaran manusia pendukung dan morfologinya. untuk membedah permasalahan tersebut diperlukan metode yang baik dan benar, dengan mengutamakan keilmuan. Oleh sebab itu itu teknik pengumpulan data survei, wawancara dan studi pustaka penting dalam tatanan kronologi urutan uraian menjawab pertanyaan penelitian. pendekatan etnoarkeologi menjadi panutan penting dalam data etnografi dan arkeologi, meskipun selama penelitian belum mendapatkan data ekskavasi tentang perahu di Maluku dan Maluku Utara, namun pengetahuan (knowledge) tentang perahu itu sendiri manjadi nilai penting dalam tatanan bermasyarakat.

Studi etnoarkeologi dalam kajian ini (Tanudirjo, 2009) pendekatan etnoarkeologi terbagi dalam 3 (tiga) kelompok; pertama disebutkan kajian etnografi yang secara informal memberikan informasi kepada ahli arkeologi. Disebutkan etnoarkeologi informal kalau pengamatan etnografi 
dilakukan hanya sekilas saja, tetapi dimaksudkan untuk kepentingan arkeologi. Kedua etnoarkeologi yang mengkaji secara khusus salah satu aspek tertentu budaya yang masih hidup, misalnya mata pencaharian, teknologi atau religi. Ketiga etnoarkeologi yang menelaah secara mendalam seluruh budaya masyarakat yang masih hidup sebagai konteks penciptaan budaya bendawi.

\section{PEMBAHASAN}

Pembahasan dalam makalah ini tidak membatasi dalam konteks administrasi Provinsi Maluku dan Maluku Utara, namun pembahasan dalam makalah ini konteks Orang Maluku menggambarkan Kepulauan Maluku, yaitu Maluku dan Maluku Utara. Pengetahuan lokal tentang nama-nama perahu dapat ditemukan dengan rangkaian kata yang berbeda-beda, namun nama-nama perahu tersebut merujuk pada jenis perahu cadik atau yang terbuat dari sebuah batang pohon yang digali bagian dalam membentuk sebuah perahu. Dan perahu yang terbuat dari susunan papan kayu dengan kelengkapan gading pada sisi bagian dalamnya.
Sebutan lokal untuk perahu terdiri dari semang, habo, belang, arumbae, lepa-lepa atau lep-lep, kora-kora, juanga, lakafunu (Wattimena, 2017) (Lapian, 2008; Wattimena, 2016) (Penyusun, 2014, 2016) (Penyusun, 2017) (Lacsina, 2015) (Horridge, 2015) (Wolter R Hetharia, Eliza R De Fretes, 2016). Konstruksi Perahu secara garis besar terdiri dari badan perahu, layar atau cadik dan ruang untuk manusia di perahu tersebut. Kondisi demikian terkonteks dalam simbolsimbol yang terdapat pada perahu, sehingga simbol-simbol tersebut memaknai khasanah budaya bendawi sebuah perahu serta manusia pendukungnya.

Secara tradisi, nama-nama simbol (lambang) adat di Maluku berhubungan dengan keberadaan benda-benda hidup dan mati di alam. Biasanya bentuk-bentuk simbol tradisi local memiliki beberapa bentuk dasar, antara lain : titik kecil bulat, lingkaran kecil besar dan kecil matahari, burung, garis silang $\mathrm{x}$ bentuk + , belah ketupat, cicak, tumbuhtumbuhan, dan bentuk palang. Bentukbentuk simbol yang terdapat di perahu Orang Maluku, antara lain : simbol manusia, pala, cengkeh, ikan, simetris dan geometris, burung, ayam (Tamaela, 2016); (Penyusun,
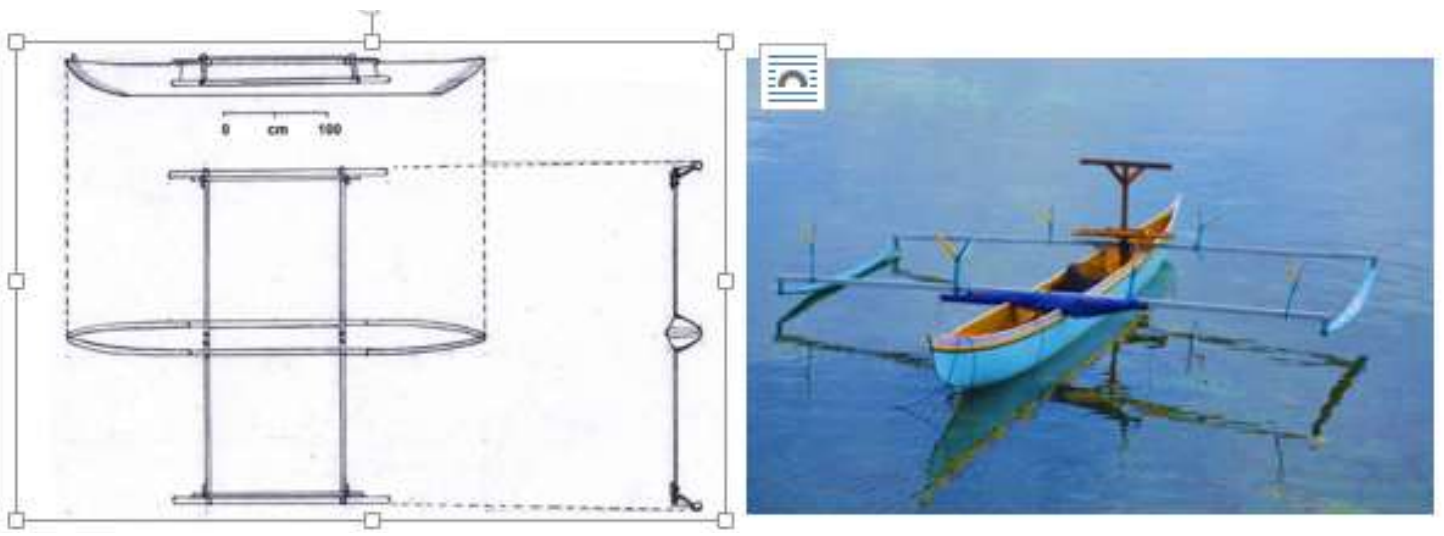

Gambar 1. Perahu Semang Atau perahu bercadik Orang Maluku, Provinsi Maluku. (Sumber: Dok. Balai Arkeologi Maluku, Tahun 2014). 

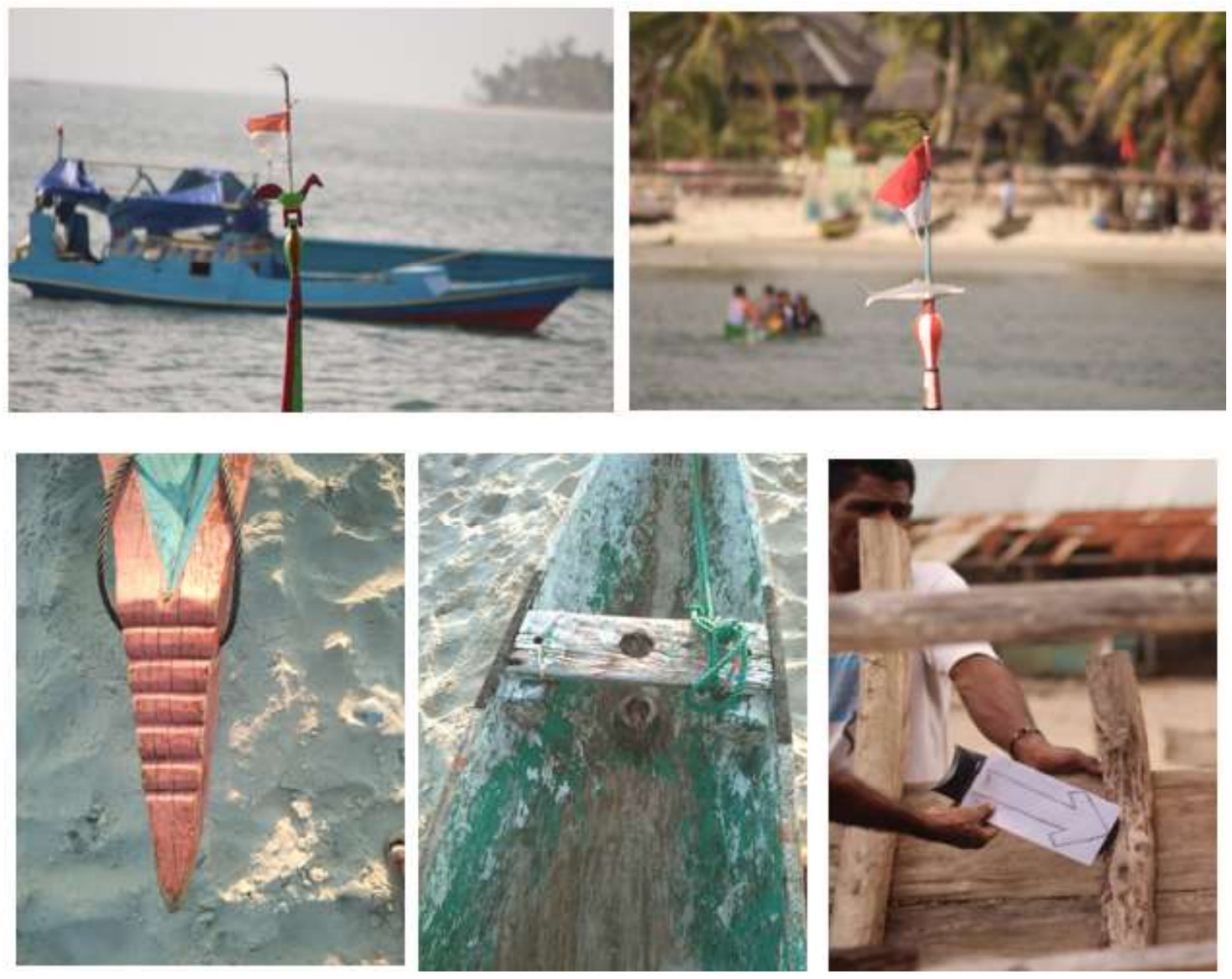

Gambar 2. Simbol-Simbol geometris, lingkaran, flora, fauna dan lingkaran (Sumber: Dok, Balai Arkeologi Maluku, 2014;2018).

2014, 2016, 2017, dan 2018). Kondisi bentuk-bentuk simbol tersebut terdapat di perahu sebagai pelengkap perahu, dan bahkan juga sebagai konstruksi representatif kebudayaan suatu kelompok. Simbol-simbol yang terdapat di perahu bercadik maupun susunan papan kayu mempunyai makna yang holistik dengan bentuk perahu tersebut. Pemaknaan simbol, di perahu bagian dari totalitas manusia dan budaya pendukungnya.

Hasil penelitian menunjukan simbolsimbol simetris, geometris dan lingkaran ditemukan pada jenis perahu bercadik dengan posisi penempatan simbol-simbol tersebut pada bagian badan perahu, bagian cadik dan bagian penumpang atau ruang kemudi dan atau muatan perahu. Kenapa hanya pada bagian-bagian tersebut karena bagianbagian tersebut adalah kosmos dunia atas. Simbol-simbol tersebut sangat sederhana, karena hanya membentuk simeteris, lingkaran dan geometris. Karena menurut pemahaman dan pandangan masyarakat Maluku dan Maluku Utara perahu ketika sudah berada di air atau laut maka terbagi antara ruang atau bagian diatas (air/laut) dan dibawahnya. Simbol lingkaran, simetris dan geoimetris diterjemahkan dalam bentuk lingkaran matahari, huruf $\mathrm{U}$, simbol mata dan lingkaran polos, bergaris (vertikal dan horizontal). Sedangkan simbol geomteris, karena keunikannya (lingkaran) dapat ditemukan juga pada jenis perahu susunan papan kayu. Penempatan simbol ini pada 
area (bagian tengah) tempat untuk menaruh layar, pembuangan air dari dalam perahu, simbol mata (Wattimena, 2017).

Simbol flora dan fauna terdapat di jenis perahu susunan papan kayu. Simbol ini biasanya ditaruh di bagian depan dan belakang perahu. fungsi mendasar dari simbol ini adalah estetika dan etnisitas. Hasil Penelitian di Pulau Trangan (Aru selatan) Kepulauan Aru, Provinsi Maluku masih menggunakan perahu susunan papan kayu atau dikenal dengan nama belang sampai saat ini. Bahkan ketika mereka akan pergi ke Kota Dobo Ibukota Kabupaten Kepulauan Aru Provinsi Maluku untuk berbelanja kebutuhan sehari-hari, mencari ikan, bahkan aktivitas laut lainnya. Simbol fauna ikan, ayam, burung buat Orang Aru selatan adalah simbol identitas genelogis kelompok yang berasal dari daerah atau wilayah yang sama. Selain itu bentuk kepercayaan kepada leluhur atau nenemoyang yang berwujud binatangbinatang tersebut. Sehingga bagi sebagian kelompok kelarga ada larangan untuk mengkonsumsi jenis-jenis fauna tertentu.

Pengetahuan Orang Maluku tentang perahu baik itu perahu bercadik maupun susunan papan kayu adalah personifikasi dari seorang manusia (Wattimena, 2017) (Wattimena, 2016). Perahu sebagai manusia, sehingga perlakuan pun berbeda dari mulai perahu dibuat sampai digunakan. Perlakuanperlakuan tersebut meliputi : pemilihan kualitas dan kuantitas bahan baku kayu yang terbaik, tanoar atau bulan pengerjaan, persiapan peralatan, sampai pada tenaga manusia untuk proses adat mengambil bahan di hutan dan menurunkan perahu di laut.

Manusia perempuan memegang peranan penting dalam kosmos perahu Orang Maluku, karena 1) perempuan dianalogikan sebagai manusia yang suci bilamana pada saat

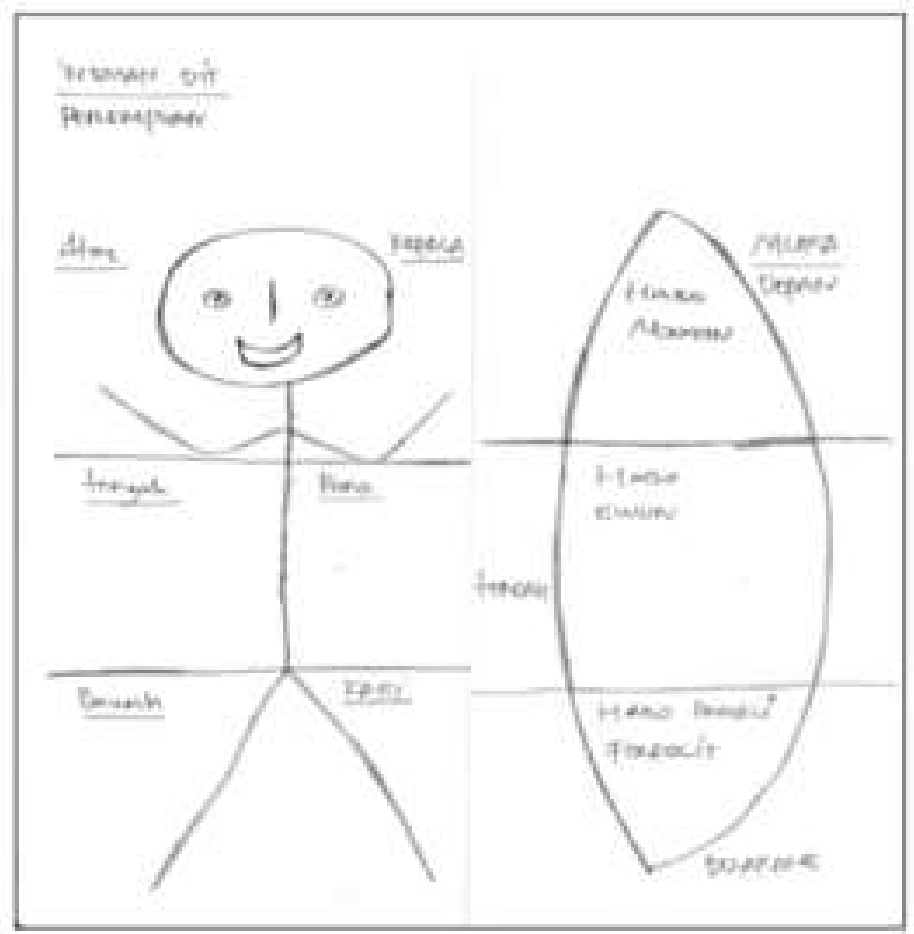

Gambar 3. Personifikasi perahu sebagai manusia perempuan (Sumber : Wattimena, 2016). 
akan melakukan pembuatan perahu dengan pengukuran (panjang, lebar, tinggi, luas) dengan menganalogikan manusia perempuan remaja yang belum mendapatkan masa haid. 2) manusia perempuan sebagai ibu atau perempuan memegang peran penting dalam sebuah keluarga batih. sehingga mencukupi kebutuhan sehari-hari dalam sistim keluarga penting. Simbol manusia dilengkapi dengan simbol-simbol pendukungnya, antara lain simbol mata terdapat di bagian depan perahu, simbol tulang belakang manusia yang terdapat pada lunas perahu, simbol perut yang terdapat di bagian dalam perahu analogi dengan muatan pada perahu (tempat muatan) atau juga sebagai simbol reproduksi (lihat Wattimena, 2016).

\section{SIMPULAN}

Simbol-simbol Austronesia di Asia Tenggara pada jenis perahu bercadik dan susunan papan kayu Orang Maluku dan Maluku Utara terdiri dari simbol mata, simbol geometris, bergaris dan lingkaran, simbol flora dan fauna. Simbol-simbol tersebut merepresentasikan tentang simbol kesuburan, simbol manusia (perempuan dan laki-laki), simbol siklus hidup (lahir, dewasa dan kematian).

\section{DAFTAR PUSTAKA}

Bellwood, P., Fox, J. J., \& Tyron, D. (2006). The Austronesians: Historical And Comparative Perspectives. The Austronesians: Historical And Comparative Perspectives. Https:// Doi.Org/10.26530/Oapen_458826

Harkantingsih, N. (2014). Pengaruh Kolonial Di Nusantara. Kalpataru Majalah Arkeologi, 4, 67-80. Https://Doi.Org/ DOI: Http://Dx.Doi.Org/10.24832/ Kpt.V23i1.51
Hersanti, N. J., Pangarsa, G. W., \& Antariksa. (2008). Tipologi Rancangan Pintu Dan Jendela Rumah Tinggal Kolonial Belanda Di Kayutangan Malang. Arsitektur E-Journal, 1(3), 157-171.

Horridge, A. (2015). Perahu Layar Tradisional Nusantara (Diterjemah). Penerbit Ombak.

Lacsina, L. (2015). 2015_The_Butuan_Boats_ Of_The_Philippine (1). 126-132.

Lapian, A. B. (2008). Pelayaran Dan Perniagaan Nusantara Abad Ke -16 Dan 17 (Cetakan Pe). Komunitas Bambu.

Liebner, H. H. (2005). Perahu-Perahu Tradisional Nusantara. Eksplorasi Sumberdaya Budaya Maritim, 53124.

Mahdi, W. (1999). The Dispersal of Austronesian Boat Forms In The Indian Ocean. Archaeology And Language, 3, 144-179.

Oktaviana, A. A., Lape, P. Van, \& Ririmasse, M. N. (2018). Recent Rock Art Research On East Seram, Maluku: A Key Site In The Rock Art Of West Papua And South East Maluku. Kapata Arkeologi, 14(2), 135. Https://Doi. Org/10.24832/Kapata.V14i2.534

Oppenheimer, S., \& Richards, M. (2001). Fast Trains, Slow Boats, And The Ancestry Of The Polynesian Islanders. Science Progress, 84(Pt 3), 157-181. Https://Doi. Org/10.3184/003685001783238989

Penyusun, T. (2014). Perahu Tradisional Di Kepulauan Maluku; Tinjauan Awal Perahu Tradisional Di Pulau Saparua, Maluku Tengah (Studi Etnoarkeologi).

Penyusun, T. (2016). Perahu Tradisional Di Kepulauan Maluku; Tradisi Pembuatan Perahu Tradisional Di Wilayah Kepulauan Kei, Propinsi Maluku (Studi Etnoarkeologi). 
Penyusun, T. (2017). Survei Arkeologi Di Kawasan Halmahera Utara, Privinsi Maluku Utara.

Penyusun, T. (2018). Budaya Penutur Austronesia Di Kepulauan Maluku; Tradisi Pembuatan Perahu Di Kepulauan Aru Provinsi Maluku.

Pham, C. M. H. (2016). An Interdisciplinary Approach To The Study Of Boats Of Central Vietnam. Journal of Indo-Pacific Archaeology, 36, 25. Https://Doi.Org/10.7152/Jipa. V36i0.14913

Ririmasse, M. N. (2016). Boat Symbolism And Social Identity In The Southeast Mollucas. Naditira Widya, 4(2), 245. Https://Doi.Org/10.24832/ Nw.V4i2.35

Ririmasse, M. N. R. (2007a). Ruang Sebagai Wahana Makna: 3(November).

Ririmasse, M. N. R. (2007b). Tinjuan Kembali Seni Cadas Di Maluku. Kapata Arkeologi, 3(4), 1-21.

Ririmasse, M. N. R. (2011). Kepulauan Maluku Tenggara.

Simanjuntak, T. (2011). Austronesia Prasejarah Di Indonesia. Austronesia \& Melanesia Di Nusantara: Mengungkap Asal Usul Dan Jati Diri Dari Temuan Arkeologis, 1-22.

Tamaela, C. I. (2016). Falsafah Siwalima Dalam Simbol-Simbol Tradisional Maluku. Menelusuri Identitas Kemalukuan, 641-666.

Tanudirdjo, D. A. (2011). Interaksi Austronesia -Melanesia: Kajian Interpretasi Teoritis. Austronesia \& Melanesia Di Nusantara: Mengungkap Asal Usul Dan Jati Diri Dari Temuan Arkeologis, 23-42.

Tanudirjo, Daud A. (2001). Islands In Between: Prehistory of The Northeastern IndonesianArchipelago.Unpublished Phd Thesis. 2(December).
Tanudirjo, Daud Aris. (2009). Memikirkan Kembali Etnoarkeologi. Jurnal Penelitian Arkeologi Papua Dan Papua Barat, 1(2), 3-15. Https:// Jurnalarkeologipapua.Kemdikbud. Go.Id/Index.Php/Jpap/Article/ View/119

Wattimena, L. (2017). Cosmology Of Habo Tetear Kei People, Southeast Molluccas. Purbawidya, 6(1), 33-42.

Wattimena, L. (2016). Budaya Maritim Komunitas Berpenutur Austronesia Di Maluku Tengah, Kepulauan Maluku. Menelusuri Identitas Kemalukuan, 519-540.

Wibisono, S. C. (2014). Arkeologi Natuna: Koridor Maritim Di Perairan Laut Cina Selatan. Kalpataru Majalah Arkeologi, 23(2), 81-150.

Wolter R Hetharia, Eliza R De Fretes, F. G. Dan A. J. T. (2016). Kora-Kora Warisan Budaya Maluku Yang Segera Dikembangkan. Menelusuri Identitas Kemalukuan, 259-288.

\section{HASIL DISKUSI}

\section{Pertanyaan}

\section{Ary Sulistyo (TACB Kota Depok)}

Apakah hanya perahu bercadik saja yang menunjukkan Austronesia di Maluku? Bagaimana dengan tradisi maritim lainnya seperti tradisi sasi di Nusa Tenggara?

\section{Jawaban}

1. Tradisi Austronesia banyak namun dalam penelitian hanya membahas mengenai perahu. Di Maluku hanya ada dua tipe perahu, perahu yang terbuat dari susunan papan kayu dan yang bercadik menggunakan satu batang 
PROSIDING - Seminar Nasional Arkeologi 2019: 101-108

pohon yang dilubangi tengahnya. Keduanya merupakan bagian dari sistem kemaritiman. Sementara tradisi sasi merupakan strategi mengelola sistem kelautan, bagian kecil dari sistem kemaritiman. 


\title{
SITUS-SITUS NEOLITIK \\ DI SEPANJANG SUNGAI TASIKMALAYA DAN LEBAK: \\ JEJAK PENUTUR AUSTRONESIA \\ DI PEDALAMAN JAWA BAGIAN BARAT
}

\section{Neolitic Sites around Tasikmalaya and Lebak Rivers: Traces of Austronesian Speakers in West Java}

\author{
Nurul Laili \\ Balai Arkeologi Jawa Barat \\ Jalan Raya Cinunuk Km. 17 Cileunyi, Bandung 40623 \\ E-mail: nurulkarangkajen@gmail.com
}

\begin{abstract}
The purpose of this paper is to reveal the traces of Austronesian speakers in the interior of western Java based on neolithic heritage. Neolithic sites in both Lebak and Tasikmalaya districts are located along the river. This paper focuses on the sites of the research results of the West Java Archaeological Center team in the Cineam and Cibeureum area. The method used is descriptive. The results showed that rivers were the preferred location for neolithic activity.
\end{abstract}

Keywords: neolithic sites, traces, Austronesian

\begin{abstract}
Abstrak
Tujuan tulisan ini akan mengungkap jejak penutur Austronesia di pedalaman di Jawa bagian barat berdasarkan tinggalan neolitik. Situs situs neolitik baik di Kabupaten Lebak dan Kabupaten Tasikmalaya terletak di sepanjang aliran sungai. Tulisan ini menitikberatkan pada situs situs hasil penelitian tim Balai Arkeologi Jawa Barat di Kawasan Cineam, Tasikmalaya dan Kawasan Cibeureum, Lebak. Metode yang digunakan adalah induktif deskriptif. Hasil penelitian menunjukkan bahwa sungai menjadi pilihan untuk lokasi aktivitas neolitik.
\end{abstract}

Kata kunci: situs neolitik, jejak, Austronesia

\section{PENDAHULUAN}

$\mathrm{N}$ eolitik merupakan periode yang ditandai dengan teknologi yang lebih kompleks dari periode sebelumnya. Beliung batu dengan teknologi upam merupakan salah satu produk yang menjadi ciri khas dari periode Neolitik. Selain beliung yang telah diupam, beberapa temuan yang mengindikasikan adanya budaya neolitik adalah peralatan gelang batu dan tembikar (Simanjuntak, 1992). Keberadaan beliung upam sering dikaitkan dengan masyarakat peladang tradisional penutur Austronesia.

Beberapa pernyataan tentang masyarakat Austronesia, ditulis oleh beberapa ahli, di antaranya adalah Bellwood yang menyatakan bahwa migrasi masyarakat penutur Austonesia dari Asia Daratan menuju Asia Tenggara Kepulauan. Masyarakat penutur Austronesia meskipun masih mahir dengan berburu dan mengumpulkan makanan tetapi telah membawa pengetahuan baru berupa pola subsistensi pertanian (Bellwood, 2000; Bellwood, 2007). 
Beberapa penelitian neolitik di Indonesia yang telah dilakukan menunjukkan adanya situs pemukiman dan situs perbengkelan. Beberapa situs neolitik telah dapat diketahui pertanggalan secara absolut. Daerah Sulawesi yaitu Situs Minanga Sipakko, Malawa, Maros, dan Leang Tuwo Mane'e. Keempat situs tersebut memperlihatkan pertanggalan antara 3500- 3800 BP. Adapun daerah Kalimantan Barat di Situs Liang Kawung menunjukkan pertanggalan $3030 \pm 180 \mathrm{BP}$ dan di Situs Nangabalang pertanggalan yang diperoleh $2550 \pm 100$ BP. Kedua situs tersebut salah satu jenis temuannya berupa beliung (Simanjuntak, 2015).

Pertanggalan 3300 BP- 3150 BP dengan produk budaya berupa tembikar berslip merah berasosiasi dengan tulang babi dan moluska ditunjukkan oleh hasil penelitian di Kepulauan Maluku. Adapun pertanggalan 3500 BP dengan produk budaya berupa pecahan tembikar berasosiasi dengan tulang babi diperoleh dari penelitian di Kepulauan Nusa Tenggara dan Timor (Simanjuntak, 2015).

Pertanggalan 1650-800 BC dengan temuan fragmen tembikar bercampur dengan alat serpih obsidian, batu lainnya, dan batu asah merupakan petunjuk neolitik di Pulau Sumatera yaitu di Situs Bukit Arat, Kerinci. Situs lain di Pulau Sumatera yaitu Benua Keling, Pasemah, Sumatera Selatan menunjukkan pertanggalan $1550 \mathrm{BC}$ dengan temuan berupa tembikar polos, beliung, dan tulang manusia (Simanjuntak, 2015).

Pulau Jawa terdapat beberapa situs neolitik, salah satunya berada di Ponjen, Purbalingga, Jawa Tengah. Produk budaya di Ponjen terindikasi sebagai situs perbengkelan dengan temuan berupa gelang dan beliung batu. Pertanggalan di situs tersebut adalah $5570 \pm 210$ BP . Situs lain di Pulau Jawa berada di Song Keplek, Punung, Jawa Timur.
Situs tersebut menunjukkan pertanggalan $3260 \pm 110 \mathrm{BP}$ dengan produk budaya berupa tembikar polos dan beliung(Simanjuntak, 2015). Di Kabupaten Jember juga diperoleh situs neolitik, yaitu Situs Kendenglembu. Situs tersebut menghasilkan produk budaya berupa tembikar slip merah, alat serpih, bilah, beliung paruh, dan belincung dengan pertanggalan $1332 \pm 35$ BP (Noerwidi, S dan Priyatno, Hadi, 2011).

Pergerakan manusia penutur Austronesia menurut Mahirta (2006), berdasarkan penelitian di Kepulauan Indonesia bagian timur, terdapat dua macam pola permukiman prasejarahAustronesia, yaitu (1) permukiman tersebar di sepanjang pantai jika pulau yang dihuni tidak terlalu besar, seperti pulau Kayoa dan Pulau Gebe di Maluku utara, dan (2) permukiman berkembang memanjang ke pedalaman sejajar dengan alur sungai, misalnya situs-situs Kalumpang di Sulawesi Barat dan permukiman tradisional etnis Dayak di Kalimantan (Mahirta, 2006).

Beberapa situs neolitik di Jawa Barat sebagian besar berada di pedalaman dan berada di sepanjang aliran sungai. Situs-situs tersebut diantaranya di Kawasan Cineam Tasikmalaya dan Kawasan Cibeureum di Kabupaten Lebak. Bertolak dengan hal tersebut akan dibahas apa saja ragam temuan serta faktor apa yang melatarbelakangi dipilihnya sungai sebagai lokasi beraktivitas. Metode yang digunakan adalah induktifdeskriptif. Pengetahuan tentang ragam dan pilihan lokasi diharapkan akan mendapatkan informasi tentang aktivitas penutur Austronesia di Jawa bagian barat, khususnya di Kawasan Cineam dan Kawan Cibeureum.

\section{PEMBAHASAN}

Kabupaten Lebak dan Kabupaten Tasikmalaya memiliki banyak potensi 
tinggalan arkeologi, terutama tinggalan yang berkait dengan aktivitas neolitik. Situs-situs neolitik di Kabupaten Lebak dan Kabupaten Tasikmalaya menempati lahan di sepanjang tepian sungai. Sebaran situs- situs neolitik di Kabupaten Tasikmalaya berada di Kawasan Cineam, sedangkan wilayah Kabupaten Lebak, sebaran situs neolitik berada di Kawasan Cibeureum (Gambar 1).

Tinggalan neolitik di Kawasan Cineam diperoleh di Situs Pasirgadung, Blok Makam, Pasirwangi, Sindangsari, Blok Negla, dan Sukabakti. Keseluruhan situs secara lateral berada di sepanjang sungai. Sungai-sungai yang mengaliri Kawasan Cineam yaitu Sungai $\mathrm{Ci}$ Goang dan $\mathrm{Ci}$ Riri. Di kawasan ini, jarak situs dengan sungai kurang dari 500 meter. Di antara sungai tersebut, yaitu $\mathrm{Ci}$ Goang terdapat kandungan batu rijang yang merupakan sumber bahan baku dalam aktivitas neolitik, yaitu pembuatan beliung.
Jarak situs dengan sungai yang terdekat adalah Situs Blok Negla dengan Ci Riri atau juga dikenal sebagai Ci Ampanan berjarak sekitar $50 \mathrm{~m}$. Urutan terdekat berikutnya adalah Situs Sindangsari berjarak 75 meter dengan Ci Goang, Situs Pasirgadung dengan jarak $100 \mathrm{~m}$ dengan Ci Goang, dan Situs Pasirwangi berjarak sekitar $125 \mathrm{~m}$ dari Cigoang. Adapun situs yang terjauh dari sungai adalah Situs Blok makam berjarak $250 \mathrm{~m}$ dengan Ci Goang dan Situs Sukabakti berjarak sekitar $250 \mathrm{~m}$ dengan Ci Ampanan (Ci Riri).

Indikasi adanya aktivitas neolitik tergambar dari temuan yang berupa tinggalan sisa perbengkelan beliung persegi. Artefak yang diperoleh di Situs Pasirgadung berupa bahan baku, hasil produksi, serta limbah dari pembuatan beliung. Ragam temuan di antaranya berupa tatal, serpih, bahan baku, calon beliung, serta beliung jadi. Selain hal tersebut, artefak lain berupa mata panah juga diperoleh di Situs Pasirgadung.

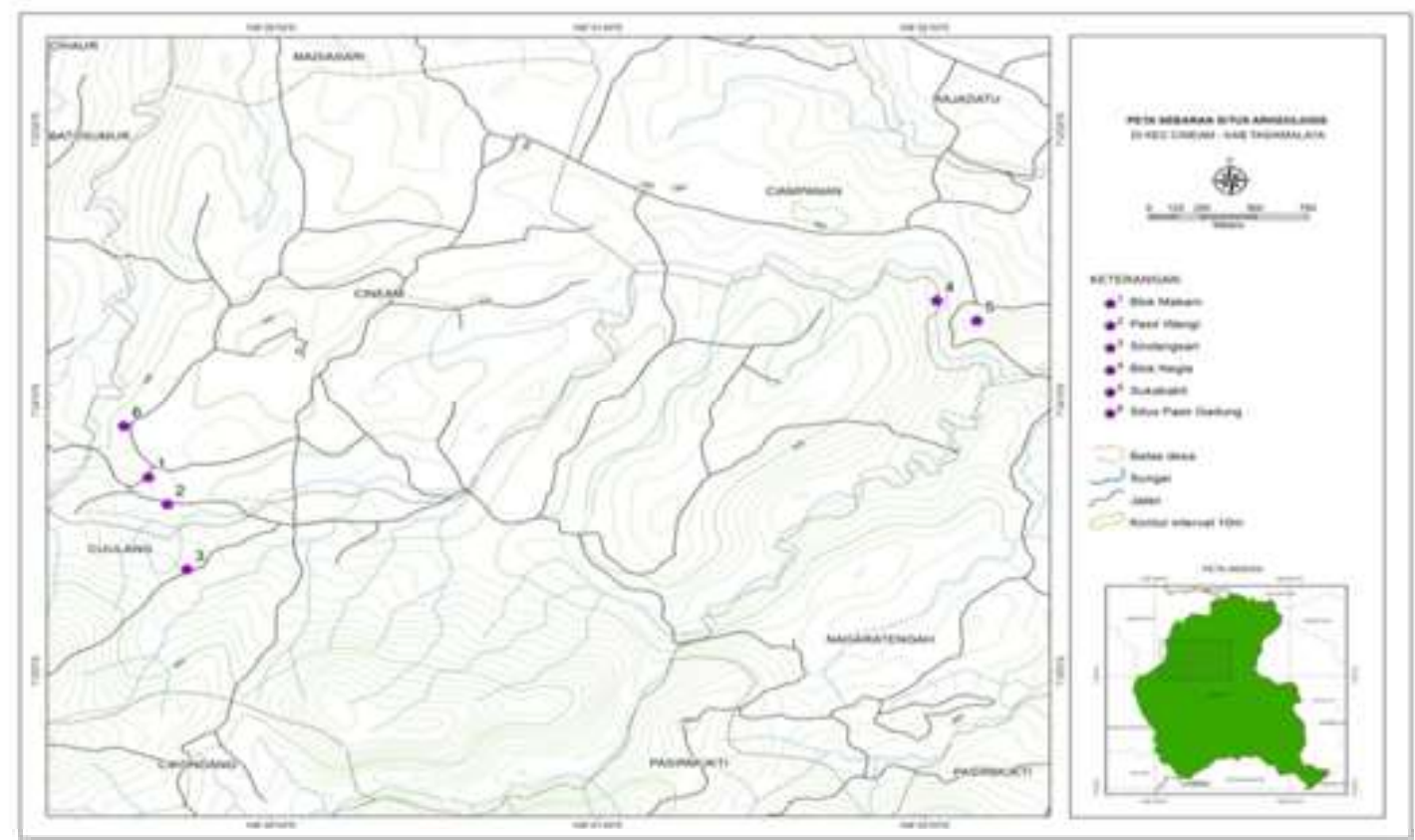

Gambar 1. Kawasan Cineam (Sumber: Laili, 2015). 


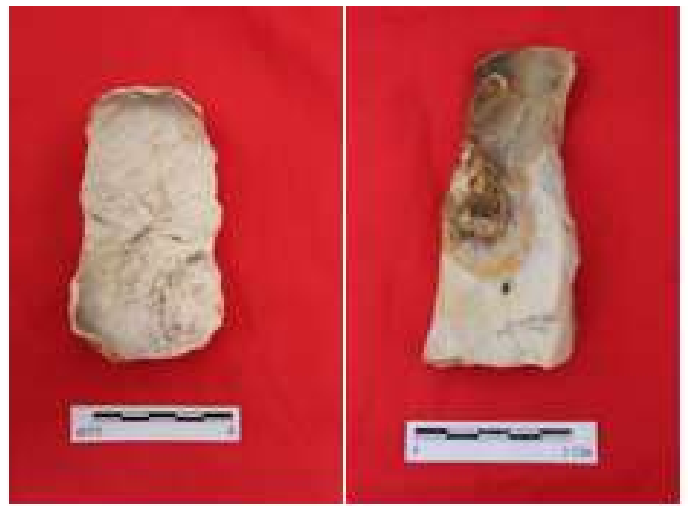

Gambar 2. Calon Beliung di Kawasan Cineam (Sumber: Dok. Balai Arkeologi Jawa Barat, 2015).

Situs-situs lain di Kawasan Cineam yaitu situs Blok Makam tinggalan neolitik berupa sebaran tatal dan tiga calon beliung, situs Sindangsari berupa sebaran tatal dan serta dua calon beliung, situs Blok Negla diperoleh sebaran tatal dan satu calon beliung. Situs lain, yaitu Sukabakti tinggalan arkeologis yang diperoleh berupa sebaran tatal dan empat calon beliung. Situs dengan tinggalan arkeologis paling sedikit adalah situs Pasirwangi dengan tinggalan berupa sebaran tatal (Gambar 3).

Situs-situs neolitik di kawasan Cibeureum secara administratif dibagi 2 wilayah, yaitu di Kecamatan Maja dan Kecamatan Curugbitung. Wilayah Kecamatan Maja terdapat 9 (sembilan) situs neolitik dan Wilayah Kecamatan Curugbitung terdapat 10 (sepuluh) situs neolitik.Keseluruhan situs secara lateral berada di sepanjang aliran sungai (Ci) Beureum.

Hasil penelitian menunjukkan bahwa situs-situs neolitik berada di tepian sungai, baik sungai utama maupun anak sungai. Situs-situs tersebut berpola mengelompok, yaitu (1.) Kelompok A, terdiri atas tiga situs yaitu Situs Kampungbaru, Jabing I, dan Jabing II. Ketiga situs berada di aliran anak sungai (Ci) Beureum. Kelompok A ini merupakan lokasi paling timur dari situssitus neolitik di kawasan Ci Beureum; (2)

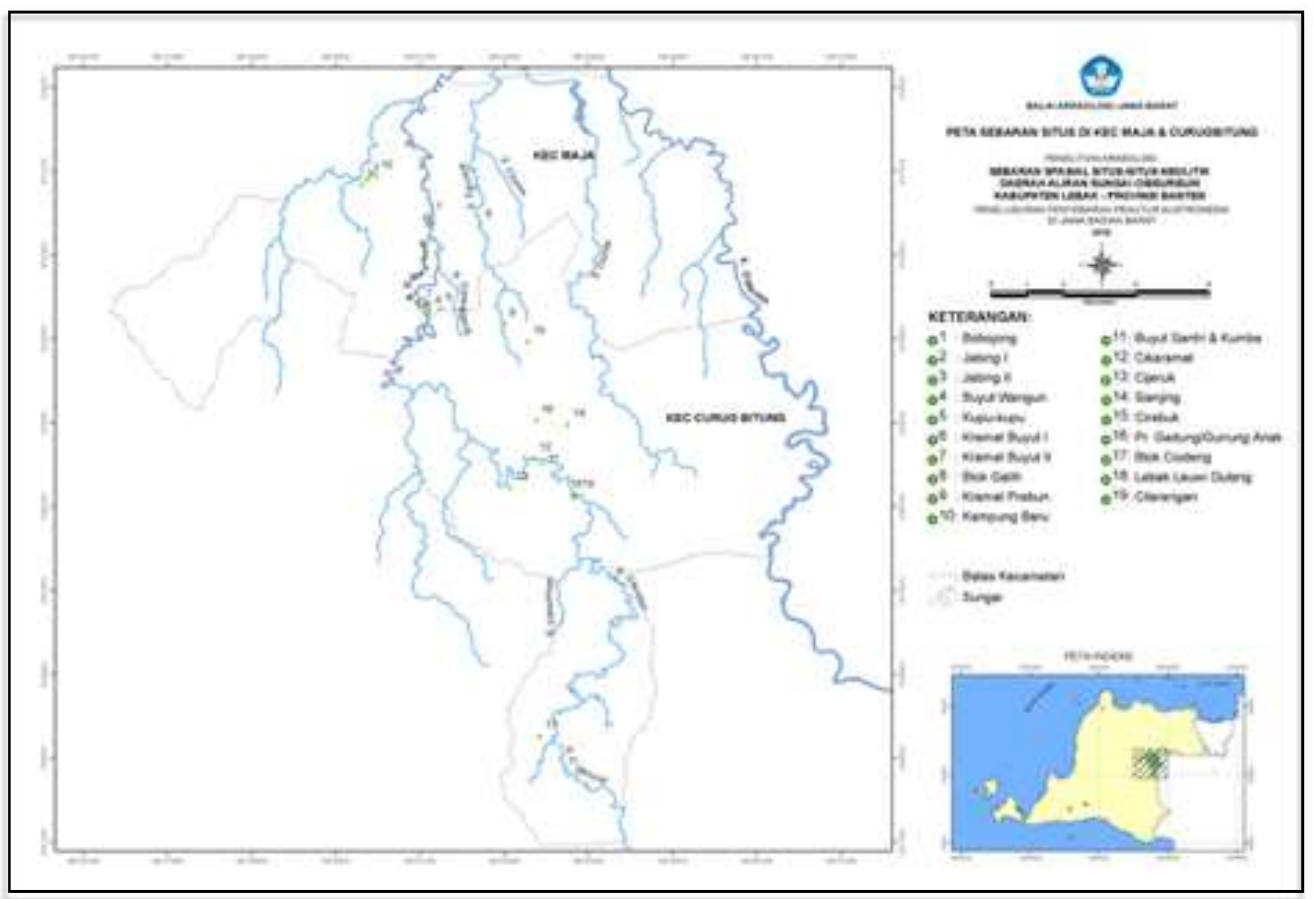

Gambar 3. Peta Kawasan Cibeureum (Sumber: Laili, 2019). 
Kelompok B berada di aliran sungai utama, yaitu Ci Beureum, lokasinya berada di sebelah timur dari Kelompok A. Situs yang berada di kelompok B terdiri atas lima situs, yaitu Bobojong, Buyut Wangun, KupuKupu, Kramat Buyut I, dan situs Kramat Buyut II; (3) Kelompok C juga berada di aliran sungai utama, yaitu $\mathrm{Ci}$ Beureum ke arah hilir. Lokasi kelompok C berada di sebelah selatan kelompok B. Situs-situs di kelompok berada di pertemuan antara $\mathrm{Ci}$ Beureum dengan anak sungainya. Situssitus yang berada di kelompok ini adalah Buyut Santri dan Kumba, Cikaramat, Cijeruk, Sianjing, dan situs Pasirgadung; (4) Kelompok D terdiri atas tiga situs yaitu Situs Blok Galih, Kramat Prebun, dan Cirebuk. Ketiga situs berada di aliran anak sungai Cibeureum, yaitu Ci Pining. Kelompok A berada di sebelah timur dari kelompok B, dan (5) Kelompok E berada paling selatan dari situs-situs yang diteliti. Pada kelompok E hanya terdiri satu situs, yaitu situs Blok Ciodeng. Situs ini berada di pertemuan anak sungai $\mathrm{Ci}$ Beureum, yaitu $\mathrm{Ci}$ Tundun dan $\mathrm{Ci}$ Gelung.

Ragam artefak yang diperoleh di kesembilan belas situs neolitik di Kawasan Cibeureum, di antaranya di situs Bobojong temuan berupa bahan berupa fosil kayu/kayu terkersikan (silicified wood), rijang (chert), jaspis, kalsedon, ditemukan di permukaan tanah (ladang) dan di sungai; situs Jabing I dan Jabing II temuan arkeologi berupa sumber bahan fosil kayu/kayu terkersikan (silicified wood), rijang (chert), jaspis, kalsedon serta tatal, serpih, dan calon beliung; situs Buyut Wangun temuan neolitik berupa bahan dari fosil kayu/kayu terkersikan (silicified wood), rijang (chert), jaspis, kalsedon, ditemukan di teras bukit. Selain bahan di situs ini juga diperoleh beliung, tatal, dan serpih; situs Kupu-Kupu berupa calon beliung, tatal, batu inti, serpih, dan bahan. Bahan tersebut berupa fosil kayu/kayu terkersikan (silicified wood), rijang (chert), jaspis, kalsedon, ditemukan di teras bukit.

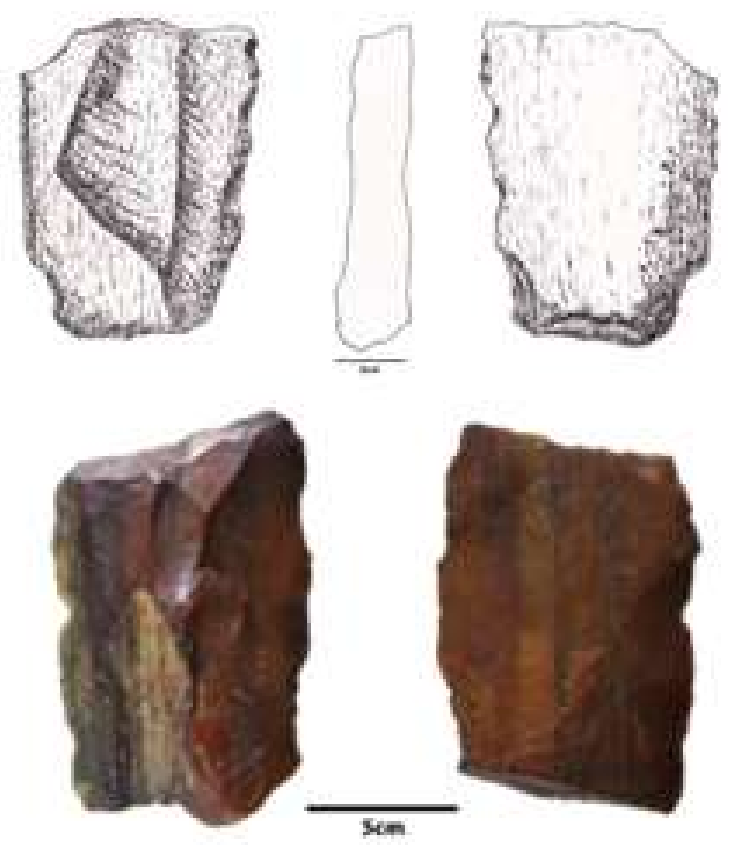

Gambar 4. Calon beliung berbahan silicified wood (Sumber: Dok, Balai Arkeologi Jabar 2019).

Situs-situs lain di Kawasan Cibeureum yang terdapat tinggalan neolitik diperoleh juga di situs Kramat Buyut I dan Kramat Buyut II. Temuan tersebut antara lain berupa calon beliung, batu inti, dan serpih. Selain itu juga terdapat bahan yang berasal dari fosil kayu/kayu terkersikan (silicified wood) dan rijang (chert); situs Blok Galih temuan neolitik berupa calon beliung, serpih, tatal, dan bahan fosil kayu, rijang, kalsedon; situs Kampung Baru temuan yang diperoleh berupa sebaran tatal dan serpih di teras sawah berbahan fosil kayu (silicified wood) dan rijang (chert); situs Buyut Santri dan Kumba temuan neolitik berupa sebaran tatal, calon beliung, dan bahan menyebar hampir di sepanjang permukaan kebun berupa fosil kayu (silicified wood) dan chert (rijang). 
Selain hal tersebut masih terdapat situs lain, diantaranya adalah situs Cikaramat. Temuan diperoleh di lahan ini berupa sumber bahan fosil kayu/kayu terkersikan (silicified wood). Hasil penelitian tahun 2005 oleh tim Balai Arkeologi Bandung memperoleh sebaran tatal dan serpih di lokasi situs (Sudarti, dkk, 2005); Situs Cijeruk temuan berupa beliung, sebaran tatal dan serpih fosil kayu; Situs Sianjing temuan neolitik berupa calon beliung, tatal, batu inti, serpih, dan bahan fosil kayu/kayu terkersikan (silicified wood), rijang (chert), jaspis, dan kalsedon.

Enam situs lain, yaitu situs Cirebuk kandungan tinggalan neolitik berupa calon beliung, serpih, tatal, dan bahan fosil kayu, rijang, kalsedon; situs Pasirgadung/Gunung Anak berdasarkan penelitian 2005 oleh tim peneliti Balai Arkeologi Bandung di situs ini diperoleh tatal dan serpih dari fosil kayu (Sudarti, dkk, 2005); Situs Blok Ciodeng temuan yang diperoleh berupa beliung dan sebaran bahan di permukaan yaitu fosil kayu (silicified wood) dan rijang (chert); Situs Leuwidulang temuan diperoleh di permukaan kebun singkong berupa sumber bahan fosil kayu/kayu terkersikan (silicified wood), rijang (chert) dan tatal serta serpih; Situs Cilarangan tinggalan arkeologi berupa sebaran bahan berupa fosil kayu/ kayu terkersikan (silicified wood) dan rijang (chert). Selain bahan di situs ini juga diperoleh beliung, batu inti, dan serpih; dan Situs Kramat Prebun dengan tinggalan arkeologi berupa bahan fosil kayu/kayu terkersikan (silicified wood)

Situs-situs neolitik baik di Kawasan Cineam maupun Kawasan Cibeureum diindikasikan sebagai lokasi dengan jejak ativitas perbengkelan. Penempatan situssitus neolitik di DAS Cibeureum mempunyai pola mengelompok. Pengelompokan situs- situs neolitik linear memanjang sejajar dengan alur sungai, yaitu Ci Beureum dan anak-anak sungainya. Demikian juga situssitus yang berada di Kawasan Cineam menempati daerah tepian sungai yaitu $\mathrm{Ci}$ Goang dan Ci Riri. Hal tersebut selaras dengan hasil penelitian Mahirta (2006), di Indonesia timur, terdapat macam pola permukiman prasejarah Austronesia yaitu permukiman berkembang memanjang ke pedalaman sejajar dengan alur sungai.

Pemilihan lokasi untuk aktivitas neolitik di Kawasan Cineam dan Kawasan Cibeureum selaras dengan teori lokasi. Suatu aktivitas dilakukan dengan mempertimbangkan tata ruang dan alokasi geografis, khususnya jarak dan aksesibilitas (Robinson, 2006). Penempatan situs neolitik di Ci Beureum, $\mathrm{Ci}$ Goang, dan Ci Riri (Ci Ampanan) menunjukkan bahwa sungai merupakan sumber air bagi manusia dan mendukung dalam aktivitas pembuatan beliung. Di antara sungai tersebut, yaitu $\mathrm{Ci}$ Goang terdapat kandungan batu rijang yang merupakan sumber bahan baku dalam aktivitas neolitik yaitu pembuatan beliung.

Sungai memiliki potensi sebagai penyedia air dan sebagai pemenuh kebutuhan masyarakat pendukung. Manusia pendukung situs bengkel memilih lokasi sepanjang daerah aliran sungai karena dapat mendukung kegiatan bengkel beliung persegi. Penentuan lokasi situs bengkel mempertimbangkan efisiensi dan efektivitas kerja.

Situs-situs bengkel yang ditempatkan di daerah aliran sungai disebabkan oleh tebing-tebing yang rendah, sungainya lebar, tidak deras, dan dangkal. Kondisi tersebut dipengaruhi oleh sungai yang berkelokkelok sehingga pengikisan tidak lagi berupa pendalaman sungai tetapi lebih ke arah samping atau tebing. Akibatnya tebing- 
tebing di daerah tersebut lebih rendah dibanding bagian hulu, sedangkan sungainya lebih lebar dibandingkan dengan daerah di atasnya atau hulu. Tingkat mobilitas manusia cenderung lebih tinggi daripada daerah hulu. Daerah hulu mempunyai tebing yang curam, aliran sungai yang deras, serta banyak jeram. Oleh karena itu, manusia pendukung bengkel tidak memilih lokasi di daerah hulu untuk aktivitasnya. Bagian hilir sungai (muara) merupakan daerah yang sering banjir sehingga daerah tersebut juga tidak dipilih oleh pendukung situs bengkel sebagai tempat aktivitasnya.

\section{SIMPULAN}

Situs-situs di Kawasan Cineam, Tasikmalaya dan Kawasan Cibeureum, Lebak berada di daerah aliran sungai, permukiman berkembang memanjang ke pedalaman sejajar dengan alur sungai. Sungai memiliki potensi sebagai penyedia air, sebagai pemenuh kebutuhan masyarakat pendukung, juga merupakan sumber penyedia bahan untuk kegiatan bengkel oleh manusia pendukung. Ci Goang dan Ci Riri di Kawasan Cineam menyediakan sumber bahan batuan berupa rijang dan kalsedon.

\section{DAFTAR PUSTAKA}

Bellwood, P. (2000). Prasejarah Kepulauan Indo-Malasyia (Revisi). PT Gramedia Pustaka Utama.

Bellwood, P. (2007). Prehistory of the IndoMalasyian Archipelago (3ed ed.). The Australian National University Press.

Laili, N. (2015). Pola Keletakan Situs-Situs Neolitik di Kawasan Cineam, Tasikmalaya. PURBAWIDYA: Jurnal Penelitian dan Pengembangan Arkeologi, Vol. 4 No., 97-108.
Laili, N. (2019). Penempatan Situs-Situs Neolitik Di Das Cibeureum Lebak Banten. Panalungtik, Vol 2. No., 77-94.

Mahirta. (2006). The Prehistory of Austronesian Dispersal to the Southern Islands of Eastern Indonesia. In T. dkk Simanjuntak (Ed.), Proceedings of the International Symposium Austronesian Diaspora and The Ethnogeneses of People in Indonesian Archipelago (hal. 141-145). LIPI.

Noerwidi, S dan Priyanto, H. (2011). Awal Kolonisasi Austronesia di Tenggara Pulau Jawa: Perspektif Situs Kendenglembu. Amerta, Vol,29. No, 45-60.

Robinson, T. (2006). Ekonomi Regional: Teori dan Aplikasinya (Revisi). Bumi Aksara.

Simanjuntak, T. (1992). Neolitik di Indonesia: Neraca dan Perspektif Penelitian. Jurnal Arkeologi Indonesia. Jurnal Arkeologi Indonesia No. 1, 117-130.

Simanjuntak, T. (2015). Progres Penelitian Austronesia Di Nusantara. Amerta, 33(1), 25. https://doi.org/10.24832/ amt.v33i1.211

Sudarti, D. (2005). Pola Persebaran Situs-Situs Religi di Kecamatan Curugbitung, Kabupaten Lebak, Provinsi Banten. Bandung: Balai Arkeologi Jawa Barat

\section{HASIL DISKUSI}

\section{Pertanyaan}

\section{Budianto Hakim (Balai Arkeologi Sulawesi Selatan)}

Adanya keraguan untuk mengambil sampel dating situs Lebak dan Tasikmalaya. Seharusnya jangan ragu karena diambil dari lapisan tanah yang tidak terganggu. Apakah tadi yang 
dianggap tatal tersebut benar tatal atau serpih? Tidak menutup kemungkinan Austronesia dapat memproduksi alat serpih mengadopsi teknologi dari pendahulunya. Contohnya beberapa lokasi yang diekskavasi di Sulawesi masih menemukan serpih. Mungkin ada pertemuan dengan non-Austronesia di mana mereka saling tukar informasi teknologi.

\section{Jawaban}

1. Nurul Laili, S.S. (Balai Arkeologi Jawa Barat)

Peneliti akan coba menganalisis dengan lebih detail. 


\title{
PEWARISAN TEKNOLOGI LOGAM \\ PADA MASYARAKAT LAMPUNG
}

\section{The Inheritance of Metal Technology in Lampung Society}

\author{
Nanang Saptono, Rusyanti, Endang Widyastuti \\ Balai Arkeologi Jawa Barat \\ Jalan Raya Cinunuk km. 17, Cileunyi, Bandung \\ E-mail: nanangsaptono@gmail.com
}

\begin{abstract}
Metal technology is known to the public starting at the end of the cultivation period. The early days of metal technology recognition are often called the paleometalic period. In Austronesian society, metal technology is often controlled by the Dongson culture. Culture developed from Vietnam around 1000 BC or early AD. From Vietnam spread throughout Southeast Asia including in the archipelago. Some of the objects of the Dongson culture that were found were in the form of bronze objects such as nekara, bronze vessels, and bronze axes. In a younger period, namely during the Hindu-Buddhist period (Classical Period) in Lampung, many metal objects were also found. Bronze objects from the paleometalic period such as nekara and bronze vessels were probably of great importance. Based on these objects, it appears that there are a cultural inheritance of metal processing technology (bronze) deposits from the paleometalic period to the Islamic-colonial period. This study seeks to reveal the existence of this cultural inheritance. The disclosure of cultural inheritance will be reviewed based on the research findings in the Mount Rajabasa area. Based on this review, the question of cultural inheritance will be known.
\end{abstract}

Keywords: technology, inheritance, metal, Islamic-Colonial period

\begin{abstract}
Abstrak
Teknologi logam dikenal masyarakat mulai pada akhir masa bercocok tanam. Masa awal dikenalnya teknologi logam sering juga disebut masa paleometalik. Pada masyarakat Austronesia, teknologi logam sering kali dikaitkan pula dengan budaya Dongson. Kebudayaan ini berkembang dari Vietnam pada sekitar 1000 SM atau awal Masehi. Dari Vietnam menyebar ke seluruh Asia Tenggara termasuk nusantara. Beberapa benda hasil budaya Dongson yang ditemukan adalah berupa benda-benda perunggu seperti misalnya nekara, bejana perunggu, dan kapak perunggu. Pada masa-masa yang lebih muda yaitu pada masa Hindu-Buddha (Masa Klasik) di Lampung banyak juga ditemukan benda-benda logam. Pada benda-benda perunggu yang berasal dari masa paleometalik seperti nekara dan bejana perunggu mungkin merupakan benda impor. Berdasarkan benda-benda tersebut terlihat ada pewarisan budaya khususnya teknologi pengolahan logam (perunggu) dari masa paleometalik hingga masa Islam-Kolonial. Kajian ini berusaha untuk mengungkap adanya pewarisan budaya tersebut. Pengungkapan adanya pewarisan budaya akan diulas berdasarkan temuan-temuan hasil penelitian di kawasan Gunung Rajabasa. Berdasarkan ulasan tersebut akan diketahui adanya pewarisan budaya dimaksud.
\end{abstract}

Kata kunci: teknologi, pewarisan, logam, masa Islam-Kolonial 


\section{PENDAHULUAN}

$\mathrm{P}_{\mathrm{b}}$ osisi kepulauan nusantara dia antara dua benua dan dua samudra menjadikannya sebagai kawasan yang mudah dikunjungi dan dilalui berbagai bangsa. Sejak masa prasejarah telah terjadi migrasi manusia dari berbagai daratan menuju kawasan tropis nusantara. Pada kala Pleistosen telah terjadi migrasi manusia purba ke berbagai wilayah. Australopithecus diketahui jejaknya di Afrika Selatan dan Afrika Timur merupakan manusia purba tertua yang selanjutnya berevolusi dan bermigrasi ke seluruh penjuru. Pithecanthropus, manusia purba yang menunjukkan mengalami evolusi ke manusia modern banyak ditemukan di Asia Tenggara dan Asia Timur. Selain di kedua daerah itu, Pithecanthropus juga ditemukan di Afrika Timur dan Afrika Utara. Berdasarkan temuan-temuan jejak manusia purba inilah para ahli berkesimpulan bahwa manusia berasal dari satu tempat lalu menyebar ke daerah lain (Poesponegoro \& Notosusanto, 2009). Menurut teori out of Africa migrasi manusia dari daratan Afrika kemudian menyebar ke berbagai daerah hingga akhirnya sampai di Pulau Jawa terjadi dalam dua gelombang yaitu migrasi manusia purba dan manusia modern $(H$. sapiens) sebagai penerus manusia purba (Fachruliansyah, 2018).

Migrasi disertai persebaran budaya berlangsung terus hingga masa sekarang. Pada sekitar 2000 BP terjadi migrasi para penutur Austronesia yang ditandai dengan artefak alat neolitik. Selanjutnya, seiring dengan kemajuan di bidang pelayaran dan perdagangan regional global, hingga sekitar abad ke-4 - 5 Masehi berlangsung migrasi masyarakat yang semakin kompleks. Budaya penanda pada periode ini adalah praktek penguburan tempayan yang merupakan tradisi berlanjut prasejarah (Neolitik), bendabenda logam pengaruh Budaya Dongson, dan Megalitik (Simanjuntak, 2015). Migrasi penutur Austronesia ke Asia Tenggara dan Pasifik juga membawa pengetahuan tentang pertanian (padi, jewawut, tebu, ubi dan keladi raksasa) budaya akuatik, domestikasi ternak (babi, anjing, ayam), teknologi pelayaran, pembuatan gerabah, penggunaan beliung persegi, perhiasan kerang, tenun dan kebiasaan makan sirih (Bellwood, 2000). Berkembangnya kebudayaan Dongson di Asia Tenggara bersamaan dengan berkembangnya budaya religi, pertanian, dan teknologi.

Kebudayaan Dong Son merupakan berkembang di Vietnam pada zaman perunggu (Bronze Age), mula-mula berkembang di lembah Sungai Merah (Song Hong) di wilayah utara Vietnam. Pada waktu itu di Vietnam sudah berdiri Kerajaan Van Lang dan Au Lac. Melalui aktivitas kerajaan seperti perdagangan, budaya Dongson memberi pengaruh besar di berbagai wilayah Asia Tenggara, termasuk wilayah kepulauan Nusantara pada sekitar tahun 1000 SM hingga awal abad Masehi. Masyarakat Dong Son, yang juga dikenal dengan sebutan Lac atau Lac Viet, adalah masyarakat yang bermata pencaharian sebagai petani dan peternak (Jusoh, 2016; Wijaya, 2013).

Benda logam terutama perunggu yang merupakan hasil budaya Dongson banyak ditemukan di wilayah nusantara. Beberapa benda perunggu budaya Dongson juga ditemukan di wilayah Lampung. Selain benda-benda perungu hasil budaya Dongson, di Lampung juga ditemukan beberapa benda logam perunggu. Benda-benda berbahan perunggu ditemukan pada situs-situs yang berasal dari masa yang lebih muda. Berdasarkan temuan-temuan tersebut, kajian 
ini akan membahas permasalahan seputar adanya pewarisan teknologi logam pada masyarakat Lampung. Kajian dilakukan melalui analisis terhadap beberapa objek benda perunggu yang ditemukan di Lampung khususnya di daerah Lampung Selatan. Metode pembahasannya melalui analisis morfologis terhadap tinggalan benda logam tersebut.

\section{PEMBAHASAN}

\section{Persentuhan dengan Budaya Logam}

Kehidupan manusia dengan budaya bercocok tanam semakin meningkat dengan dikenalnya teknologi pengolahan logam. Penemuan teknik peleburan, pencampuran, penempaan, dan pencetakan jenis-jenis logam telah menghasilkan berbagai barang termasuk untuk keperluan bercocok tanam. Sebelum dikenal teknik pencampuran, peleburan tembaga dan emas sudah lebih dulu dikenal karena kedua jenis logam ini sangat mudah dilebur. Penemuan teknik peleburan dan pencampuran telah menghasilkan benda-benda yang lebih kuat. Bahan campuran inilah yang dikenal dengan perunggu (Poesponegoro \& Notosusanto, 2009, hal. 293).

Beberapa perkakas bercocok tanam yang terbuat dari logam, umumnya perunggu atau besi, semakin meningkatkan produksi pangan sehingga sering terjadi surplus. Berdasarkan temuan-temuan artefak sejenis budaya logam di Indonesia mendapat pengaruh dari budaya Dongson dari Vietnam. Bendabenda perunggu hasil budaya Dongson misalnya nekara, bejana perunggu, kapak corong, candrasah, arca-arca perunggu, dan perhiasan. Di Lampung, pernah ditemukan benda-benda perunggu (Gambar 1). Di Desa Gedung Aji, Tulangbawang pernah ditemukan nekara. Di Desa Sriminosari, Kecamatan Labuhan Maringgai, Lampung Timur pernah ditemukan nekara dan bejana perunggu. Benda-benda itu sekarang tersimpan di Museum Ruwa Jurai.
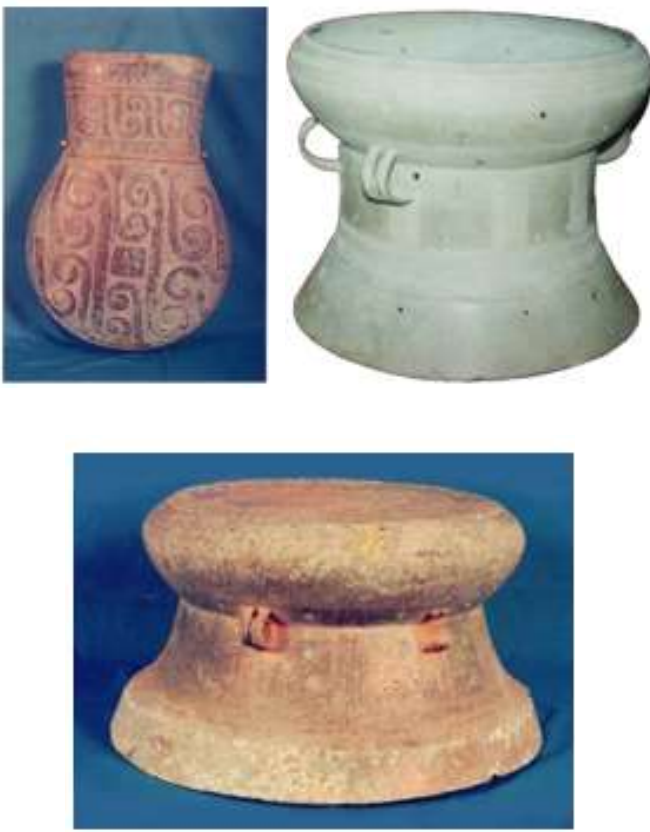

Gambar 1. Benda-benda perunggu yang ditemukan di Lampung (Sumber: Dokumen Museum Ruwa Jurai)

\section{Benda-Benda Logam di Lampung}

Di Museum Ruwa Jurai tersimpan beberapa benda, diantaranya merupakan benda berlatarkan pada budaya HinduBuddha yang ditemukan dari kawasan Way Sekampung (Tim Penelitian, 2009). Bendabenda tersebut adalah sebagai berikut.

\section{- Arca Dewi Sri (1)}

Arca dengan nomor koleksi 2634 (No. Inventaris 04.104; No. Registrasi 2201), ditemukan di Desa Banjar Agung, Kecamatan Talang Padang, Kabupaten Tanggamus (Gamabr 2). Arca berukuran tinggi keseluruhan $23,5 \mathrm{~cm}$ terbuat dari 
bahan perunggu, pada beberapa bagian berlapis emas. Arca digambarkan dengan sikap badan berdiri tegak (samabangga) di atas lapik teratai (padmasana).

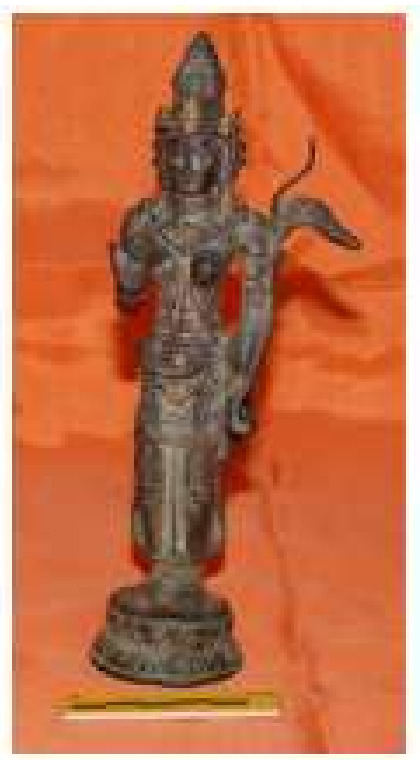

Gambar 2. Arca Dewi Sri yang ditemukan di Desa Banjar Agung (Sumber: Dokumen Balai Arkeologi Jawa Barat, 2009).

\section{- Arca Dewi Sri (2)}

Arca Dewi Sri (2) dengan nomor koleksi 3976 ditemukan di Pekon Rantau Tijang, Kecamatan Pugung, Kabupaten Tanggamus. Ukuran arca, tinggi keseluruhan $19 \mathrm{~cm}$ berbahan perunggu, pada beberapa bagian berlapis emas. Arca digambarkan dengan sikap badan berdiri tegak (samabangga) di atas lapik teratai (padmasana). Tangan kanan menjulur ke bawah dengan telapak tangan terbuka mengarah ke atas. Sikap seperti ini disebut varahasta atau varadahasta. Tangan kiri menjulur ke bawah telapak mendatar menjepit tangkai padi.

\section{- Arca Durgamahisasuramardini}

Arca dengan nomor koleksi 3685 (No. Inventaris. 04.287; No. Registrasi 3858) ini ditemukan di Desa Wana, Kecamatan
Labuhan Maringgai, Kabupaten Lampung Timur (Gambar 3). Arca berukuran tinggi $20,5 \mathrm{~cm}$, terbuat dari bahan perunggu. Durgamahisasuramrdini diwujudkan dalam sikap berdiri di atas kerbau dengan kaki terbuka, badan agak miring (sikap alidha).

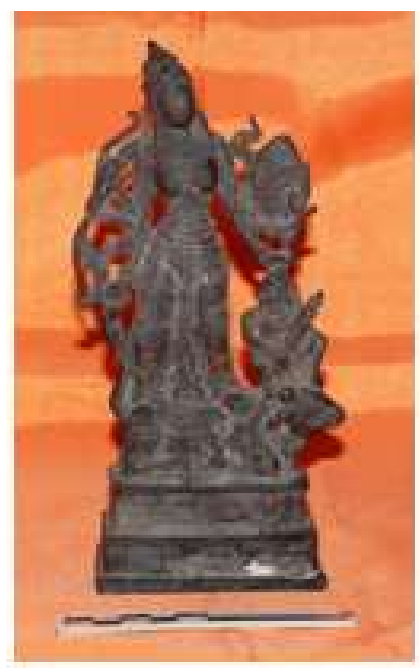

Gambar 3. Arca Durgamahisasuramrdini ditemukan di Desa Wana (Sumber: Dokumen Balai Arkeologi Jawa Barat, 2009).

\section{- Arca Buddha}

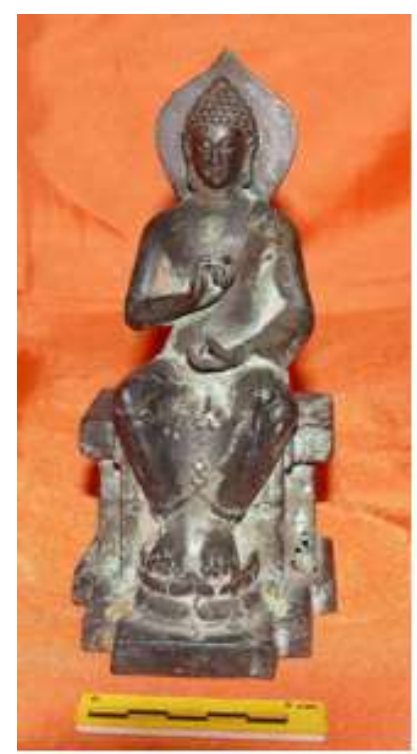

Gambar 4. Arca Buddha ditemukan di Desa Ketapang (Sumber: Dokumen Balai Arkeologi Jawa Barat, 2009). 
Arca Buddha dengan nomor koleksi 3044 (No. Inventaris 04.2789) ditemukan di Desa Ketapang, Kecamatan Penengahan, Kabupaten Lampung Selatan (Gambar 4). Arca yang terbuat dari bahan perunggu berukuran tinggi $16 \mathrm{~cm}$ ini digambarkan dalam posisi duduk sedang bersemedi di atas lapik berbentuk kubus. Kedua kaki bertumpu pada bantalan padma. Posisi tangan ditekuk di depan dada dalam sikap memutar roda dunia (dharmacakramudra).

\section{- Arca Avalokiteswara}

Arca dengan nomor koleksi 695 (No. Inventaris 04.2775) ditemukan di Desa Ketapang, Kecamatan Penengahan, Kabupaten Lampung Selatan (Gambar 5). Arca setinggi $34,5 \mathrm{~cm}$ terbuat dari bahan perunggu. Arca dalam posisi berdiri di atas lapik padma.

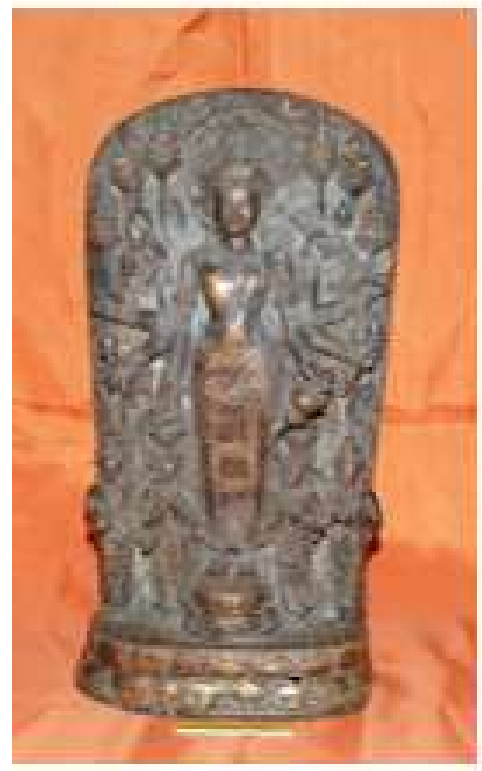

Gambar 5. Dyani Bodhisatwa Avalokiteswara ditemukan di Desa Ketapang, Kecamatan Penengahan, Lampung Selatan (Sumber: Dokumen Balai Arkeologi Jawa Barat, 2009).

Di belakang arca dilengkapi sandaran (stella) berbentuk persegi semakin melebar ke atas dan membulat pada bagian puncak. Di bagian atas stella terdapat hiasan bulan sabit di kiri dan bulan purnama di kanan.

\section{Bukti-Bukti Pewarisan Budaya}

Kebudayaan pada dasarnya merupakan kekayaan manusia yang bersifat abstrak (gagasan, pikiran, ucapan) maupun konkret (benda) yang berkaitan dengan kehidupan manusia itu sendiri. Kebudayaan tidak datang secara tiba-tiba. Kebudayaan terbentuk dan berkembang melalui proses belajar (Koentjaraningrat, 1990, hal. 180). Proses belajar dalam pembentukan kebudayaan pun bermacam-macam misalnya mulai dari internalisasi, sosialisasi, enkulturasi, hingga asimilasi (Koentjaraningrat, 1990, hal. 228-256). Begitupun dalam budaya teknologi logam pada masyarakat Lampung. Proses panjang dari masa prasejarah hingga masa kini telah menghasilkan suatu budaya teknologi metalurgi. Beberapa artefak budaya yang telah ditemukan di beberapa lokasi merupakan jejak-jejak yang tertinggal.

Jejak-jejak masyarakat penutur Austronesia di Indonesia telah banyak ditemukan. Menurut Peter Bellwood (2000, hal. 299-313), masyarakat penutur Austronesia berasal dari pesisir pantai China bagian selatan kemudian menyebar ke Taiwan dan ke wilayah lainnya di selatan dan barat. Penyebaran ke wilayah barat kemungkinan mengikuti alur darat hingga ke Thailand kemudian mengikuti aliran Sungai Perak yang berhulu di wilayah Thailand mengalir sampai di wilayah Kerajaan Perak Malaysia, dan akhirnya sampai di kawasan Sumatera bagian utara. Alur lain yang dimungkinkan adalah melalui jalur China bagian selatan terus ke Taiwan kemudian ke Filipina untuk kemudian ke Kalimantan dan terus ke Sumatera bagian utara (Wiradnyana, 
2017). Migrasi para penutur Austronesia tidak berhenti di Sumatera bagian utara tetapi terus menyebar ke selatan.
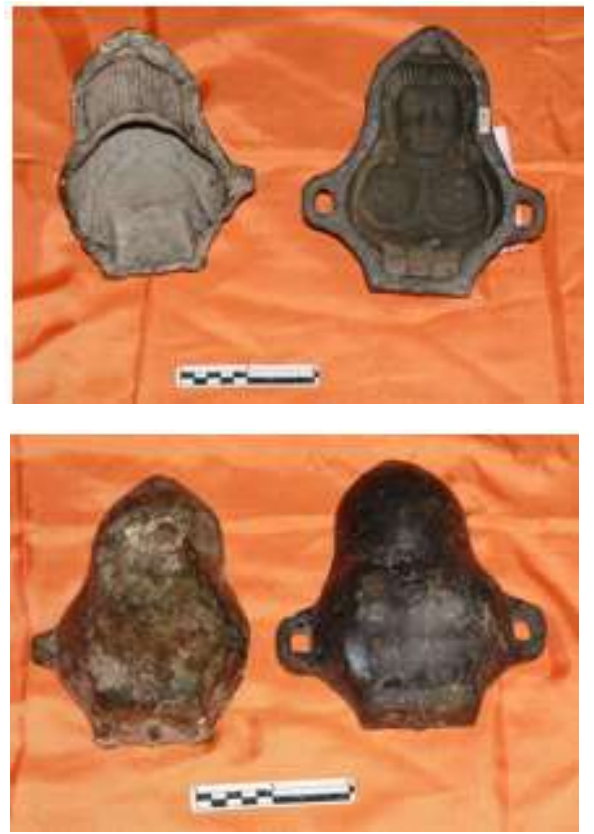

Gambar 6. Cetakan arca ditemukan di Desa Rajabasa, Kecamatan Kalianda, Lampung Selatan (Sumber: Dokumen Balai Arkeologi Jawa Barat, 2009).

Interaksi antara masyarakat penutur Austronesia dengan masyarakat nusantara memacu terjadinya perkembangan peradaban yang menyangkut berbagai bidang kehidupan. Organisasi sosial terbentuk dalam wujud kelompok-kelompok sosial di bawah kepemimpinan tradisional. Pada kelompok masyarakat tercipta spesialisasi kelompok misalnya kelompok yang mengurusi kepercayaan, undagi, petani, pedagang, dan pengarung samudera (pelayar). Kompleksitas masyarakat seiring dengan perkembangan kehidupan di lingkup regional. Kegiatan pelayaran dan perdagangan regional-global semakin marak di Kepuluan Nusantara. Tiga penanda mengenai kompleksitas budaya pada periode ini, yakni (1) penguburan tempayan, (2) benda-benda logam sebagai pengaruh budaya Dongson, dan (3) bangunanbangunan megalitik (Simanjuntak, 2015).
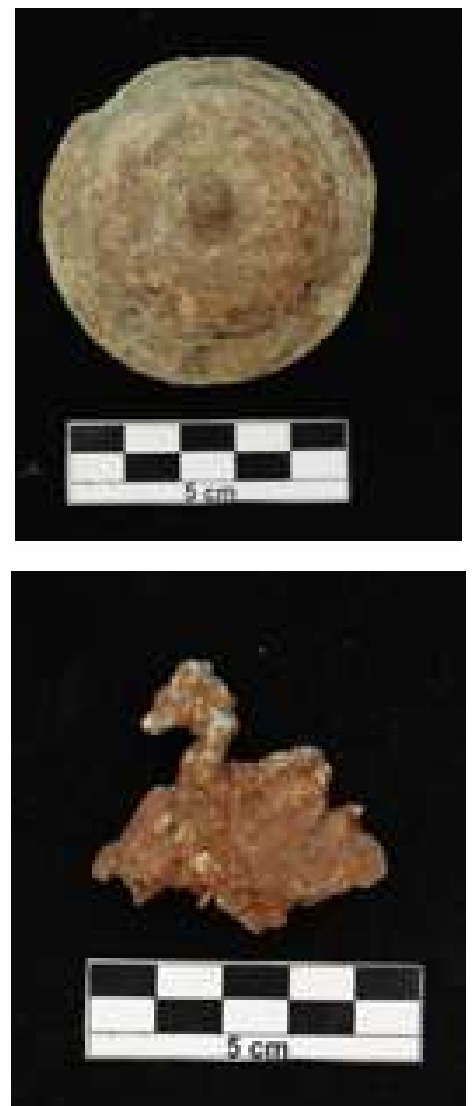

Gambar 7. Tutup perunggu dan terak perunggu yang ditemukan pada ekskavasi di situs Kuripan Saka (Sumber: Dokumen Balai Arkeologi Jawa Barat, 2018).

Salah satu jejak budaya masyarakat penutur Austronesia yang ditemukan di Lampung adalah benda-benda yang terbuat dari logam. Keberadaan benda logam di Lampung menandai adanya interaksi antara masyarakat Lampung dengan dunia luar. Benda-benda seperti nekara dan bejana perunggu pada awalnya merupakan barang dagangan. Selanjutnya benda-benda perunggu tipe lokal yang berfungsi untuk kebutuhan lokal banyak ditemukan. Bendabenda itu secara morfologis mencirikan era sejarah hingga masa-masa yang lebih muda lagi. Beberapa arca dewa-dewa Hindu dan 
arca Buddha banyak ditemukan di kawasan Lampung.

Benda logam yang pada awalnya merupakan barang impor, pada masa selanjutnya tampak sudah diproduksi setempat sehingga menunjukkan bahwa teknologi cetak tuang logam sudah dikuasai masyarakat Lampung. Salah satu benda tinggalan yang menunjukkan sudah dikuasainya teknologi logam adalah cetakan arca (Gambar 6). Alat ini ditemukan di Desa Rajabasa, Kecamatan Kalianda, Kabupaten Lampung Selatan (Tim Penelitian, 2009). Cetakan dibuat untuk mencetak arca kinara kinari. Kinara - kinari merupakan makhluk kahyangan yang berwujud setengah manusia setengah burung. Dalam kehidupan di kahyangan, mereka bertugas selain sebagai penjaga kalpataru juga sebagai seniman-seniman kahyangan yang memberikan pertunjukanpertunjukan kesenian di istnana kahyangan (Istanto \& Syafii, 2017, hal. 24). Pada beberapa relief lepas (tanpa ada kaitan cerita), digambarkan sedang memainkan beberapa instrumen musik. Cetakan terdiri dua bagian, bagian depan berukuran tinggi $18 \mathrm{~cm}$ lebar $11,5 \mathrm{~cm}$ dan dalam $6 \mathrm{~cm}$ dengan ketebalan $1 \mathrm{~cm}$. Bagian belakang berukuran tinggi $20 \mathrm{~cm}$ lebar $15 \mathrm{~cm}$ kedalaman $16 \mathrm{~cm}$.

Jejak teknologi logam ada juga yang ditemukan secara insitu berupa sisa-sisa pengecoran logam. Jejak tersebut ditemukan dalam ekskavasi di situs Kuripan Saka (Saptono et al., 2018). Situs Kampung Kuripan Saka secara administratif termasuk di wilayah Dusun Banyuurip Kuripan, Desa Kuripan, Kecamatan Penengahan, Lampung Selatan. Secara geografis berada pada posisi 5०43'37.36" LS dan 105'40'43.29” BT pada ketinggian $55 \mathrm{~m}$ di atas permukaan laut. Situs Kuripan Saka merupakan salah satu bekas permukiman masa Radin Intan dihuni pada tahun 1817 - 1828. Masa ini dalam periodesasi sejarah budaya di Indonesia termasuk dalam masa Islam-Kolonial.

Lahan situs dikelilingi sungai alam dan parit. Way Tulung mengalir di sebelah utara lahan situs. Pada sisi lainnya terdapat aliran parit. Jejak perkampungan yang masih tersisa berupa benteng tanah yang berada di sisi selatan dan utara. Posisi benteng sisi selatan memanjang dengan orientasi barat timur. Kedua ujung benteng berada di tepi parit. Benteng sisi utara juga berujung pada parit. Benteng sisi utara bagian luar terdapat cekungan (parit). Pengamatan di permukaan tanah menemukan beberapa artefak berupa pecahan keramik. Di sebelah utara ujung timur benteng sisi utara terdapat batu tegak berbentuk silindrik. Ekskavasi pada kotak LU 5 spit 3 menemukan benda logam berupa tutup dan di kotak LU 6 spit 3 ditemukan terak jejak pengolahan logam perunggu (Gambar 7).

Berdasarkan temuan benda-benda logam khususnya perunggu di kawasan Lampung terdapat perkembangan dalam hal cara mendapatkannya. Benda-benda logam prasejarah seperti nekara dan bejana perunggu didapatkan melalui sistem perdagangan. Artinya, benda-benda tersebut ada di Lampung karena hasil dari aktivitas perdagangan. Pada masa sejarah (masa Hindu-Buddha hingga Islam kolonial) sudah dapat memproduksi bendabenda perunggu. Teknologi percampuran, peleburan, dan pencetakan benda logam pada masa prasejarah belum dikuasai masyarakat Lampung. Migrasi masyarakat penutur Austronesia membawa pengetahuan tersebut dan selanjutnya diwariskan kepada generasi berikutnya.

Kebudayaan Dong Son dan beberapa kebudayaan lainnya di Asia Tenggara pada sekitar tahun 1000 SM sudah mengenal 
pengetahuan pengolahan perunggu. Teknik yang dikembangkan disebut dengan lostwax atau cire perdue. Teknik pengolahan ini merupakan proses yang sering diterapkan pada pembuatan arca dari material logam (misalnya perak, emas, perunggu). Metode cire perdue dilakukan dengan melewati beberapa tahapan dimulai dari pembentukan benda yang dikehendaki dengan bahan lilin, lengkap dengan bagian detailnya. Lilin tersebut kemudian dibungkus dengan tanah liat (clay) dan selanjutnya dipanaskan sehingga lilin menjadi cair. Selanjutnya, logam cair dituangkan ke dalam tanah liat yang telah terbentuk. Setelah dingin, tanah liat dipecahkan sehingga didapatkan benda yang dikehendaki (Wijaya, 2013). Pada masa prasejarah, dalam pembuatan benda logam juga diterapkan teknik corong (socketing technique). Teknik demikian menjadi ciri khas Asia Tenggara dan menunjukkan adanya perbedaan dengan yang diterapkan di Cina dan India. Selain metode cire perdue dan socketing technique, juga dikenal cetak langsung dengan menggunakan cetakan setangkup (Haryono, 1999).

Berdasarkan beberapa tinggalan yang ditemukan di kawasan Lampung terlihat bahwa ketiga teknik pengolahan logam tersebut telah diterapkan. Arca-arca perunggu yang pada bagian dalam terdapat corong menunjukkan teknik pencetakan sebagaimana pada kapak corong. Bendabenda keperluan sehari-hari seperti tutup, serta cetakan arca dan terak logam perunggu menunjukkan bahwa teknologi peleburan dan pencetakan logam pada masa sejarah sudah dikuasai masyarakat Lampung. Dengan adanya jejak-jejak benda dan jejak teknik pembuatan benda logam menunjukkan bahwa terjadi pewarisan pengetahuan dari masyarakat penutur Austronesia kepada generasi-generasi sesudahnya.

\section{SIMPULAN}

Benda-benda perunggu telah banyak ditemukan di daerah Lampung. Benda berupa nekara dan bejana merupakan hasil budaya Dongson yang kemungkinan bukan merupakan produk lokal. Pada masa-masa yang lebih muda telah ditemukan beberapa benda logam beripa arca. Pada masa yang lebih muda ini ditemukan pula jejak-jejak teknologi pengolahan logam. Cetakan setangkup yang ditemukan di Rajabasa dan terak perunggu yang ditemukan pada ekskavasi di situs Kuripan Saka menunjukkan bahwa pada masa itu masyarakat sudah mengenal teknologi cetak tuang logam. Berdasarkan tinggalan-tinggalan logam dan jejak teknologi logam terlihat bahwa ada jejak pewarisan teknologi dari masa prasejarah hingga masa-masa yang lebih muda lagi yaitu masa Hindu-Buddha hingga Islam-Kolonial.

\section{DAFTAR PUSTAKA}

Bellwood, P. (2000). Prasejarah Kepulauan Indo-Malaysia. Jakarta: Gramedia.

Fachruliansyah, I. (2018). Antropologi Biologi di Indonesia: Sebuah Penelusuran dan Kemungkinan Pengembangan. Antropologi Indonesia, 39(2), 90114.

Haryono, T. (1999). Dinamika Kebudayaan Logam di Asia Tengga. Humaniora, (10), 25-31.

Istanto, R., \& Syafii. (2017). Ragam Hias Pohon Hayat Prambanan. Jurnal Imajinasi, XI(1), 19-28.

Jusoh, A. (2016). Kebudayaan Dongson di Asia Tenggara: Satu Tafsiran Berdasarkan Penemuan Arkeologi. Purba - Jurnal Persatuan Muzium Malaysia, 35, $1-28$. 
Koentjaraningrat. (1990). Pengantar Ilmu Antropologi. Jakarta: PT Rineka Cipta.

Poesponegoro, M. D., \& Notosusanto, N. (2009). Sejarah Nasional Indonesia I: Zaman Prsejarah di Indonesia (R. P. Soejono \& R. Z. Leirissa, ed.). Jakarta: Balai Pustaka.

Saptono, N., Widyastuti, E., Rusyanti, Nuralia, L., Falah, W., \& Siswanto. (2018). Laporan Penelitian Arkeologi: Permukiman Masyarakat Keratuan Darah Putih di Sekitar Gunung Rajabasa Lampung Selatan. Bandung.

Simanjuntak, T. (2015). Progres Penelitian Austronesia di Nusantara. Amerta, Jurnal Penelitian dan Pengembangan Arkeologi, 33 (1), 25-44.

Tim Penelitian. (2009). Budaya Masa Pengaruh Hindu-Buddha di Kawasan Lampung. Laporan Penelitian Arkeologi. Bandung.

Wijaya, H. (2013). Nekara: Peninggalan Seni Budaya dari Zaman Perunggu. Humaniora, 4(1), 212. https://doi. org/10.21512/humaniora.v4i1.3431

Wiradnyana, K. (2017). Budaya Austronesia di Indonesia Bagian Barat Dalam Kaitannya Dengan Migrasi Out of Taiwan. Berkala Arkeologi Sangkhakala, 18(1), 22-39. https:// doi.org/10.24832/sba.v18i1.6

\section{HASIL DISKUSI}

\section{Pertanyaan}

\section{Ary Sulistyo (TACB Kota Depok)}

1. Lampung adalah wilayah di Sumatera yang paling dekat dengan Jawa. Melihat dari peninggalan yang ditemukan di Lampung, apa kaitannya dengan hunian Austronesia berbatasan dengan
Austroasiatik. Di utara Lampung ada Sumatera Selatan yang kalau tidak salah merupakan batas antara Austroasiatik dengan Austronesia?

\section{Eko Punto Hendro (Universitas Diponegoro Semarang)}

Mengenai budaya Dongson, apakah kebudayaan perunggu merupakan budaya martabat (status sosial, upacara)? Kebanyakan alat-alat perunggu berfungsi sebagai peningkat martabat, bukan untuk kepentingan praktis. Kepentingan praktis mungkin masih menggunakan batu.

\section{Jawaban}

1. Banyak situs-situs yang kelihatan seperti batas di daerah Sumatera terutama situs megalitik. Di dalam buku Megalitic Remains in South Sumatra yang disusun oleh van Der Hoop, kawasan Sunda dimasukkan sebagai kawasan "South Sumatra". Sehingga menurut Hoop Sunda merupakan batasnya. Banyak situs di Jawa Barat yang berparit, memiliki pola hunian yang mirip. Mengenai bentuk rumah, rumah Austronesia berbentuk rumah panggung. Di Sunda memiliki rumah tradisional panggung, sementara di Jawa rumahnya tidak panggung. Mungkin pada masa yang dahulu, batas tersebut berada di daerah Sunda, kemudian bergeser ke Lampung. Di Jawa Barat tidak ditemukan dolmen, sementara banyak ditemukan dolmen di Lampung dan juga di wilayah timur Indonesia. Hal tersebut mungkin bisa dikatakan sebagai anomali yang perlu diteliti lebih lanjut. Belum ditemukan manusia sezaman Austronesia di Lampung. Untuk batas tersebut memang harus dikaitkan dengan manusianya. 
Belum adanya ekskavasi lebih lanjut di Lampung. Tinggalan tertua yaitu dari masa neolitik hanya ditemukan di permukaan sehingga belum ditemukan tinggalan prasejarah yang secara stratigrafi menunjukkan kronologi. Temuan paling tua di Lampung berasal dari abad ke-7 M.

2. Di Lampung, temuan logam besi banyak ditemukan, namun untuk logam perunggu hanya ditemukan dalam jumlah yang sedikit. Sehingga mungkin yang diproduksi memang benda-benda yang bermartabat. Pada satu situs di Lampung, ditemukan sebuah terak perunggu bersamaan dengan temuan yang mirip dengan tutup pedupaan. Di Lampung daerah selatan, juga ditemukan cetakan arca yang dapat memproduksi benda ritual. Di Lampung juga hanya menemukan tiga alat perunggu yaitu dua nekara dan satu bejana. Bejana perunggu merupakan benda yang hanya sedikit ditemukan. Pertama kali ditemukan di wilayah Kerinci, kemudian Lampung, Madura, dan Subang. 


\title{
MELACAK JEJAK FITUR PARIT KUNO MASYARAKAT LAMPUNG: JEJAK MIGRASI AUSTRONESIA JALUR BARAT?
}

\author{
Tracing of a The Feature Lampongese Ancient Drain: \\ The Western Route of Austronesian Migration?
}

\author{
Rusyanti, Nanang Saptono, Endang Widyastuti \\ Balai Arkeologi Jawa Barat \\ Jalan Raya Cinunuk KM.17 Cileunyi Kabupaten Bandung 40623 \\ E-mail: rusyanti08@gmail.com
}

\begin{abstract}
Since 1995, the ancient settlement sites were found in the region of Lampung occupied in the watershed areas (DAS). The research results up to the year of 2018 in West Lampung found a consistent pattern to the emergence of ancient features assumed as ancient moat or trenches. The traces of ancient moat or trench features have not been intensively researched and still leave questions about the ins and outs. The comparison study with similar sites in DAS Way Sekampung also found trenches both in natural and artificial formed. In macro comparison, the trench occupies the topography of different regions, the highlands and the lowlands. The temporary observations of the pattern of trenching settlements have found that the dominance of natural trench formations was discovered in mountainous regions (highland) and on the active fault, while the artificial moats emerged in lowland and floodplain-prone areas. The temporary assumption is made that this moat is a form of adaptation to the environment. In addition to Lampung, the existence of a moat site was also found in Thailand in the period $500 \mathrm{BCE}-600 \mathrm{AD}$. It gave rise to the alleged linkage of the surrounding moats as the migration trail brought by the western Austronesian speakers since the Prehistoric period.
\end{abstract}

Keywords: moat, trench, ancient settlement, Lampung, Austonesia.

\begin{abstract}
Abstrak
Sejak tahun 1995, situs-situs permukiman kuno ditemukan di wilayah Lampung menempati daerah-daerah aliran sungai (DAS). Hasil penelitian hingga tahun 2018 di Lampung Barat menemukan pola yang konsisten terhadap munculnya jejak fitur yang disebut sebagai parit atau siring. Jejak fitur parit hingga saat ini belum diteliti secara intensif dan masih menyisakan pertanyaan tentang seluk beluknya. Perbandingan studi pustaka dengan situs-situs sejenis di DAS Way Sekampung juga mendapati parit-parit baik alami maupun buatan. Secara makro perbandingan parit tersebut menempati topografi wilayah yang berbeda, yaitu di dataran tinggi dan dataran rendah. Hasil pengamatan sementara terhadap pola sebaran permukiman berparit mendapati dominasi bentukan parit alami ditemukan di wilayah pegunungan dan pada jalur sesar, sedangkan parit buatan muncul pada wilayah dataran rendah rawan banjir. Asumsi sementara parit dibuat sebagai bentuk adaptasi terhadap lingkungan. Selain di Lampung, keberadaan situs berparit juga ditemukan di Thailand pada periode 500 SM-600 AD hal tersebut memunculkan dugaan adanya keterkaitan perilaku pembuatan parit keliling sebagai jejak migrasi yang dibawa oleh penutur Austronesia jalur barat sebelum 400 tahun yang lalu.
\end{abstract}

Kata kunci: Parit, fitur, permukiman kuno, Lampung, Austronesia. 


\section{PENDAHULUAN}

$\mathrm{L}$ ampung merupakan wilayah di ujung

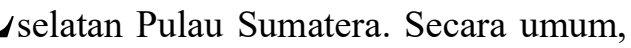
topografi wilayah Lampung bagian barat hingga tenggara berupa perbukitan dan bagian tengah dan timur berupa daratan alluvial dan rawa-rawa. Daerah Lampung dialiri oleh empat sungai utama dari Barat ke Selatan, yaitu Way Semangka, Way Seputih, Way Tulang bawang dan Way Sekampung. Berdasarkan data arkelogis, di tepian sungai-sungai itu banyak ditemukan permukiman kuno. Secara umum, tipologi bentuk permukiman disekitar aliran sungai tersebut seperti di Way Tulang Bawang dan Way Sekampung memiliki kemiripan, yaitu berupa benteng tanah dengan dan tanpa parit (Saptono, 2000:144-166; Laili, 2007: 8189; Laili, 2008:31-44; R.r Triwurjani, 2010: 570-575) sedangkan di Way Seputih data permukiman yang ada berupa perkampungan yang sudah memasuki masa pengaruh Islam (abad 17 M) (Sarjiyanto, 2007: 1-16).

Di aliran anak sungai Way Semangka, yaitu di Way Rubok yang mengalir di wilayah Lampung Barat, ditemukan delapan lokasi yang diduga sebagai permukiman kuno yang tersebar di empat desa. Kedelapan situs tersebut, yaitu Pulau Pinang, Tanjung Raya, Hujung Langit, Kehidupan, Batu Putih, Negeri Ratu, Batu Raja, dan Kurungan Aji. Dua situs diantaranya, yaitu di Tanjung Raya dan Hujung Langit terdapat Prasasti dari Abad ke-10 M beraksara Jawa Kuno bahasa Melayu Kuno, yaitu Prasasti Tanjung Raya 1 \& 2, dan Prasasti Hujung Langit (Rusyanti, 2014).

Dalam beberapa kali survei telah dilakukan penggambaran denah permukiman. Denah-denah permukiman tersebut berupa petak-petak yang dibatasi dengan bentukanbentukan lahan berupa saluran-saluran. Bentukan lahan berupa saluran-saluran tersebut berada di tengah atau mengelilingi denah permukiman dengan ukuran yang bervariasi. Masyarakat sekitar menyebutnya dengan parit. Keberadaan parit-parit tersebut diketahui membagi lahan situs ke dalam beberapa bagian. Apa fungsi dan mengapa parit tersebut dibuat belum diketahui kaitannya dengan keberadaan situs. Tulisan ini merupakan eksplorasi awal tentang keberadaan parit-parit kuno tersebut yang seringkali ditemukan di situs-situs permukiman di Lampung. Dugaan sementara, bentuk-bentuk parit tersebut juga mengingatkan pada budaya-budaya yang ada di nusantara dengan pendahulunya yang berasal dari Taiwan dan China daratan. Penelusuran ini selanjutnya dapat mengantarkan kepada pemahaman terhadap pengungkapan konsepsi alam pikir manusia dalam hal pengelolaan tata lingkungan di masa lampau.

\section{PEMBAHASAN}

Fokus penelusuran mengenai keberadan parit-parit kuno di Lampung dalam tulisan ini berawal dari pola yang teramati di Lampung Barat. Terdapat 5 (lima) lokasi permukiman yang terindikasi memiliki parit keliling, yaitu (1) Situs Tanjung Raya, (2) Situs Hujung Langit, (3) Situs Pulau Pinang, (4) Situs Kehidupan (1 dan 2), dan (5) Situs Sukarame (Batu Raja, Punjung, Puncak, dan Negeri Ratu). Kronologi situs-situs tersebut diperoleh data kisaran $10 \mathrm{M}$ menurut data prasasti (Damais, 1995) dan 10-19 M, berdasarkan analisis keramik (Widyastuti, 2010; 2011). Berikut deskripsi mengenai situs-situs berparit tersebut.

\section{Situs Tanjung Raya}

Situs Tanjung Raya terletak di Desa Tanjung Raya, Kecamatan Sukau. Situs dikenal dengan sebutan pepulau atau Charmemung (pulau menggantung). 
Situs Tanjung Raya terkenal dengan keberadaan Prasasti Tanjung Raya 1 (batu datar), dan Tanjung Raya 2 (batu tegak).

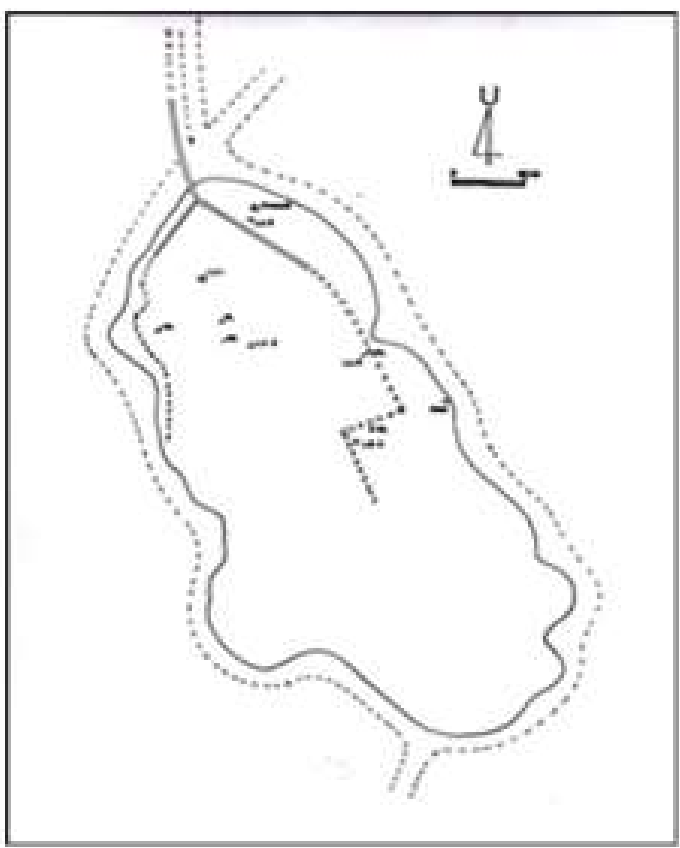

Gambar 1. Denah Situs Tanjung Raya (Sumber: Dokumentasi Balai Arkeologi Jawa Barat, 2012).

Situs Tanjung Raya muncul pada publikasi L.C.H Damais dan N.J. Krom tahun 1995 menyebutkan bahwa Prasati Tanjung Raya beraksara Jawa Kuno, Bahasa Melayu Kuno. Prasasti Tanjung Raya 1, berupa batu datar terdapat goresan yang sudah aus dan tidak terbaca, kemungkinan berasal dari abad ke-10 M. Sedangkan Prasasti Tanjung Raya 2 berupa batu tegak berbunyi "batu pahat", kemungkinan berasal dari abad ke-14 M (Damais, 1995). Di situs ini terdapat sebaran fragmen keramik, tembikar dan temuan dua arca dari batu tufa di tebing situs. Jejak Parit kuno terlihat mengelilingi situs dengan lebar dan kedalaman 20-40-meter dan ditumbuhi semak serta pohon bambu (Gambar 1). Pada dasar parit (siring) berupa kolam yang difungsikan sebagai sawah dan kolam ikan (Rusyanti, 2012).

\section{Situs Hujung Langit}

Situs Hujung terletak di Desa Harakuning Jaya, Kecamatan Sukau. Situs dikenal juga dengan keberadaan Prasasti Hujung Langit (919 M) yang pertama kali dilaporkan oleh tim Pegawai Dinas Topografi pada tahun 1912 kemudian disusul pembacaan oleh L.C Damais pada tahun 1954-1957, de Casparis, dan Krom. Prasasti Hujung Langit dikeluarkan oleh Punku Haji Yuwaraja Sri Haridewa untuk keperluan bangunan suci wihara di daerah Hujung Langit (Damais, 1995: 27-45).

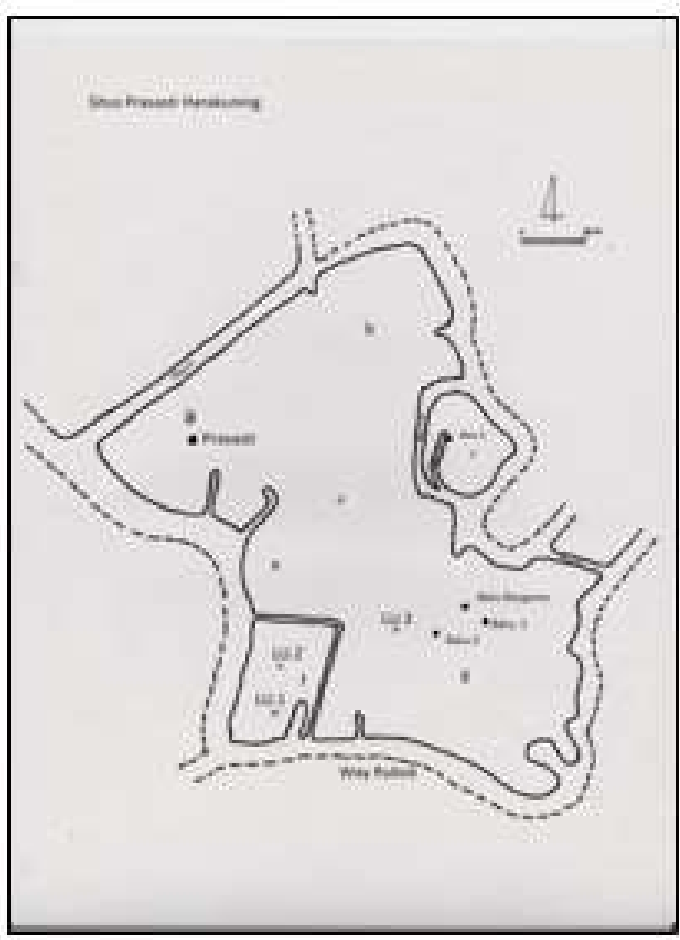

Gambar 2. Denah Situs Hujung Langit dan paritnya yang saat ini berfungsi sebagai kolam (Sumber: Dokumentasi Balai Arkeologi Jawa Barat, 2013 \& 2018). 
Di situs ini ditemukan Prasasti, sebaran fragmen tembikar, keramik, batu bergores arca/figurin, dan batu datar. Pada tahun 1995, Balar Jabar melakukan ekskavasi dan menyingkap tatanan batuan yang diduga merupakan bagian dari struktur bangunan. Lingkungan situs berada pada morfologi bergelombang dan tanah yang tertutupi material vulkanik dari formasi Ranau (Agus., et.al., 1995). Situs diduga merupakan permukiman masa klasik abad $10 \mathrm{M}$ dan berlanjut sesudahnya. Jejak parit sama dengan Tanjung Raya dengan kedalaman dan lebar 20-40 meter, ditumbuhi semak dan pohon bambu serta difungsikan saat ini sebagai kolam. (Gambar 2). Hasil overlay peta geologi Lampung Barat menunjukkan lokasi situs berada pada jejak patahan/ sesar (Rusyanti, Purwoarminta, Krama, \& Widyastuti, 2018)

\section{Situs Pulau Pinang}

Situs Pulau Pinang terletak di Dusun Suka Menanti Kecamatan Balik Bukit. Situs berupa lahan pertanian yang dikelilingi oleh siring dan di sebelah utaranya terdapat makam Keramat Batin Sakuan. Luas lahan sekitar 1 ha. Pada permukaan lahan banyak ditemukan sebaran fragmen keramik, tembikar. Di utara situs terdapat satu bukit kecil yang dikelilingi siring bernama Keramat Batin Sakuan. Jejak parit di situs ini telah terganggu oleh olah lahan pertanian berupa bentukan lahan yang menjorok ke bawah yang membagi dua petak lahan diduga merupakan kontur alami berupa tanah menurun.

\section{Situs Kehidupan 1 dan 2}

Situs Kehidupan terletak di Dusun Suka Menanti Kecamatan Balik Bukit. Situs berupa dua lahan pertanian terpisah yang masing-masing dikelilingi siring. Lahan pertama luas 1 ha diperoleh tinggalan arkeologis berupa dua batuan yang disebut Batu Ikhau, yaitu batuan pasirandan satu lagi berupa batu berbahan andesit. Batu Ikhau diyakini masyarakat setempat sebagai tempat penyembelihan perempuan cantik untuk persembahan Dewa (Rusyanti, 2014). Jejak parit pada situs ini terlihat membatasi denah lahan situs persegi empat dengan saluran menuju Way Rubok di sebelah selatan (Gambar 3).

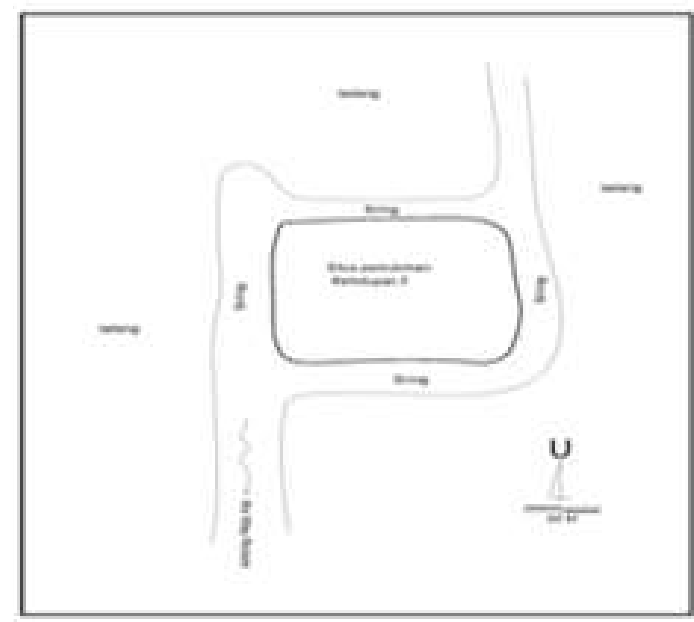

Gambar 3. Denah Situs Kehidupan 1 dan 2 dan foto lahan menurun (parit) sebagai pembatas lahan (Sumber: Dokumentasi Balai Arkeologi Jawa Barat, 2014).

\section{Situs Sukarame (Batu Raja, Punjung, Puncak, Negeri Ratu).}

Keempat situs berada di Desa Sukarami dengan jarak antar situs antara $0.5-2 \mathrm{~km}$. Empat situs berada pada posisi berderet barat-timur. Situs Batu Raja merupakan situs paling barat dari keempat situs yang ada di Sukarami berada di wilayah Pemangku Sukarami Induk, Desa Sukarami. Topografi situs bergelombang terletak di tepi sungai Way Robok. Terdapat 4 lokasi sebaran artefak arkeologi yaitu Situs Batu Raja 1, 2, 
3, dan 4 yang jaraknya relatif berdekatan dengan siring yang dangkal. Artefak yang ditemukan berupa fragmen keramik, tembikar, dan umpak batu (Rusyanti et al., 2018). Siring atau parit terlihat di sebelah selatan membentang dari barat ke timur dengan lebar dan kedalaman yang sama, yaitu $20-40$ meter.

Indikasi mengenai adanya permukiman kuno berparit di Lampung Barat sudah mulai muncul pada penelitian di tahun 1994, 1995 dan 2009. Berdasarkan penggambaran bentuk permukiman, diketahui bahwa lokasi situs Tanjung Raya dan Hujung Langit memiliki karakteristik yang sama, yaitu bidang lahan yang dikelilingi siring atau parit yang dalam dan terjal dengan kedalaman sekitar 12-25-meter dan lebar sampai dengan 40 meter. Dataran yang lebih rendah tersebut merupakan tanah subur karena merupakan daerah tadah hujan dan resapan air. Resapan air tersebut berasal dari pohon-pohon bambu diatasnya yang dahulunya sangat lebat dan berlapis-lapis. Ketika hujan air memenuhi parit tersebut sehingga seringkali disebut sebagi mata air. Di Situs Tanjung Raya parit tersebut difungsikan untuk lahan sawah tetapi di Hujung Langit masih berupa jurang dan masih didiami oleh hewan seperti monyet. Siring-siring atau parit tersebut diduga berfungsi sebagai pembatas, benteng pertahanan dan sekaligus sebagai mata air dan saluran pembuangan karena alurnya menuju aliran Way Rubok di sebelah selatan situs.

Tipologi bentuk permukiman dengan parit keliling dijumpai pula pada penelitian di tahun 2014. Bentang lahan dengan ciri dikelilingi siring dan sebaran fragmen keramik dan tembikar masih menjadi indikasi utama. Perbedaanya pada keenam permukiman kuno yang ditemukan, yaitu di Pulau Pinang, Batu Putih (Rusyanti, Laili, Hardikusmana, \& Amir, 2012), Situs
Kehidupan, Kawasan Negeri Ratu, Batu Raja yang termasuk kelompok wilayah kecamatan Sukau (Rusyanti, 2014), bentukbentuk siring yang ada tidak begitu terjal dibandingkan Situs Tanjung Raya dan Hujung langit. Siring-siring yang ada berkisar kedalaman antara 2-7-meter dan lebar 6-12-meter demikian pula dengan luas lahan yang relatif lebih kecil dibandingkan kedua situs sebelumnya.

Bentuk-bentuk permukiman dengan tipe benteng tanah dan parit juga dijumpai di DAS Sekampung dari hulu hingga hilir. Ukuran gundukan tanah ini bervariasi antara 2-6 meter, lebar parit rata-rata 2-7 meter, dan dalam parit ada yang mencapai 12 meter. Pada umumnya benteng-benteng ini ditemukan pada daerah yang mempunyai bentuk morfologi landai. Selain tinggalan berbentuk fitur, di situs-situs tersebut juga ditemukan tinggalan lainnya seperti artefak maupun ekofak. Sepintas gundukan tanah dan parit ini seakan-akan membentuk batas antara satu areal dengan areal lainnya. Di dalam ataupun diluar areal gundukan tanah dan parit sering dijumpai fitur seperti punden, gumuk, dolmen, batu lumpang, batu berjajar, komplek menhir, makam dan sebagainya sedangkan artefak yang ditemukan misalnya porselen, tembikar, manik-manik, alat batu dan lain-lain Situs-situs tersebut, yaitu Situs Gelombang, Situs Pejambon, Situs Pugung Raharjo, Situs Gedig, Situs Parigi, Situs Meris, Situs Cicilik, dan Situs Benteng Sari. Secara umum benteng-benteng tanah tersebut ada yang merupakan bentukan alami mengikuti kontur aslinya dan ada juga yang buatan (R.r. Triwurjani, 2010: 554).

\section{Asumsi dan Dugaan Sementara}

Munculnya pola umum berupa permukiman berparit di dua wilayah DAS, 
yaitu DAS Way Semangka dengan kelompok situs-situs Liwanya dan permukiman berparit di DAS Way Sekampung dilihat dari topografinya merupakan dua bentang alam yang sangat berbeda. Liwa merupakan wilayah dataran tinggi dan pegunungan yang merupakan wilayah dari rangkaian pegunungan Bukit Barisan yang membentang dari Aceh hingga Tanggamus (Highland). Lapisan tanah dan batuan yang terdapat di wilayah Liwa umumnya berasal dari endapan material gunung api yang membentuk perbukitan dan lembah dengan dominasi lapisan tuf pasiran yang lepas (moderate loose) di sebelah utara, dan lapisan tanah residu hasil lapukan material vulkanik dengan plastisitas dan kompresitas yang cukup tinggi di wilayah selatan (Anwar. et.al., 1994). Berdasarkan pengukuran umur batuan, Tuf Ranau yang diambil dari daerah

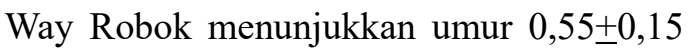
Ma, (Bellier et al., 1999), sedangkan menurut Natawijadja et al., 2017, batuan ini berumur 33.000 tahun yang lalu.

Secara geologi wilayah Liwa terletak pada zona patahan Sumatera (Anwar, et.al., 1994:1) yang berupa lajur retakan membentang dari Teluk Semangko di Selatan hingga lembah Aceh di Utara. Lajur ini membentuk segmen-segmen terban (graben) di antaranya Lembah Suoh, Antai, lembah Liwa, Way Wurkuk dan Kaldera Ranau (Bemmelen, 1949: 24-25). Sesar Sumatera merupakan sesar mendatar yang terbentuk sebagai akibat dari tumbukan lempeng yang miring (oblique) (Sieh dan Natawidjaja, 2000 dalam Aribowo 2016). Aktivitas sesar mendatar membentuk cekungan yang berpengaruh terhadap kondisi geomorfologi yang meliputi lembah sesar, kolam sesar ( $s a g$ pond), gawir sesar, bukit sesar (shutter ridge) yang membatasi aliran, dan sungai terputus (beheaded stream) (Burbank \&Anderson,
2012:Aribowo, 2016). Jejak-jejak patahan tersebut merupakan kolam-kolam mata air yang disebut sebagai siring atau parit yang mengelilingi situs sehingga akan tampak seperti pulau yang dikelilingi air (pepulau). Parit-parit alami bentukan sesar tersebut tampak jelas di Situs-situs di Liwa pada umumnya di selatan aliran Way Rubok.

Sedangkan DAS Way Sekampung berada diwilayah dataran rendah Lampung (lowland). Wilayah ini juga sekaligus merupakan wilayah dataran banjir (floodplain). Aliran Sungai Sekampung terbendung oleh Plato basalt Sukadana yang terbentuk sejaka masa pleisosen awal sehingga memicu beralihnya aliran ke tenggara yang berakibat pada terbentuknya cekungan, daerah banjir, dan rawa yang luas, salah satunya Rawa Sragi (Wurjani, 2010: 30). Jika dipetakan, pola situssitus yang berada di Liwa dan Sekampung akan berkorelasi dengan bentukan parit dengan kecenderungan yang berbeda. Paritparit di Liwa dominan merupakan parit alami sedangkan parit-parit di Sekampung diindikasi tidak semuanya alami ada beberapa merupakan parit buatan. Jika disandingkan dengan topografi wilayahnya yang rawa banjir, diduga parit-parit di Sekampung lebih sengaja dibuat untuk beradaptasi dengan banjir daripada hanya sebatas pilihan lokasi yang subur saja yang cenderung terlihat di Liwa. Kecenderungan parit-parit buatan diduga ditemukan pula di situs-situs lainnya terutama di wilayah dataran rendah, termasuk situs-situs di wilayah Tulangbawang, meskipun hal tersebut masih membutuhkan analisis lebih lanjut.

\section{Jejak Migrasi Austronesia Jalur Barat?}

Parit menurut Cambridge Dictionary adalah saluran terbuka yang digali pada 
tanah dengan fungsi pada umumnya untuk menyalurkan air atau membagi lahan. Di Indonesia, penelitian mengenai situssitus berparit dalam skala makro, belum ditemukan. Keberadaan parit-parit kuno (moat) sebelumnya telah menjadi perhatian pada penelitian arkeologi di Situs Mae Nam Mun Valley, Thailand pada tahun 1940an. Pengamatan dengan Aerial Photography Interpretation (API) atau citra satelit di Nam Mun River Valley, suatu wilayah dengan sedimentasi floodplain di timur laut Thailand menemukan 82 titik situs berparit (moat). Hasil analisis memperlihatkan keberadaan situs-situs arkeologi hampir seluruhnya lebih berkorelasi dengan paleochannels daripada sungai yang ada sekarang selain ditemukan juga jejak patahan (fault). Simpulan sementara menyatakan bahwa bentuk, pola distribusi, dan arah perkembangan situs mengikuti karakteristik yang bersifat geostruktural yang sekaligus juga memengaruhi perubahan arah dan konektivitas jaringan parit dari waktu ke waktu (Boyd, Higham, \& McGrath, 1999). Hingga kini jumlah moat yang terindikasi melalui google earth bahkan bertambah hingga 146 yang diduga muncul sejak zaman besi (iron age) sekitar 500 SM-600 A.D dengan fungsi yang masih belum diketahui (Dougald J.W \& Scott, 2015).

Indikasi paleochannel berdekatan dengan situs arkeologi pernah ditemukan di situs-situs neolitik di Cibeureum sebagai bukti kehadiran masyarakat Austronesia pada 1400-1600 tahun yang lalu di wilayah Lebak, Banten (Nurul Laili, Anton Ferdianto, Unggul Prasetyo Wibowo, Amir, Y. Hardikusmana, Desril Riva Shanti, Dede Sumiyati, 2019). Meskipun berada di dataran alluvial dan berpotensi banjir, seperti halnya karakteristik di Mun Valley dan area DAS di Lampung, tetapi di situs-situs di DAS Cibeureum tersebut tidak ditemukan parit keliling sepertihalnya yang ada di Lampung. Sehingga disimpulkan sementara bahwa ada dan tidaknya parit tidak selalu berkaitan dengan kondisi wilayah yang rentan banjir. Atau dengan kata lain fungsi parit tidak harus sebagai drainase. Kedua data tersebut sangat menarik untuk ditelisik lebih jauh yaitu kaitan wilayah Thailand dengan kearkeologian di Indonesia. Dalam peta skema sebaran Austronesia diketahui terdapat dua jalur, yaitu jalur barat dan timur (Simanjuntak, 2017).

Jalur timur mereka bermula di Taiwan, Filipina, dan masuk melalui Sulawesi, wilayah yang kerap dijadikan patokan migrasi ideal Austronesia ke Indonesia sedangkan jalur migrasi Austronesia ke arah barat termasuk Tanah Gayo (Sumatera Utara), kemungkinan dari China selatan ke Thailand lalu masuk ke Sumatera bagian utara. Hal ini didasarkan atas temuan gerabah poles merah yang memiliki pola hias yang sama dengan gerabah di Situs Ban Chiang, Thailand (Wiradnyana, 2013: 36). Meskipun masih terlalu dini, dapatlah dikemukakan kecurigaan apakah perilaku pembuatan parit keliling di Lampung merupakan kesamaan perilaku penurut Austronesia yang hadir di wilayah Sumatera pada masa lampau yang mempunyai persamaan perilaku membuat parit sama halnya dengan yang ditemukan di situs Mun Nam Valley, Thailand. Pembuktian ini menarik untuk dilakukan mengingat masih mininnya penelitian mengenai jejak Austronesia di Lampung yang seringkali dikaitkan dengan jejak artefak neolitik, baik alat batu maupun tembikarnya yang juga masih terbatas. 


\section{SIMPULAN}

Penelitian jejak-jejak permukiman di dua DAS besar di Lampung, yaitu DAS Way Semangka dan DAS Way Sekampung telah menemukan bukti-bukti permukiman kuno dengan salah satu bentukan fitur yang menonjol, yaitu didapati parit atau siring yang mengelilingi permukiman. Parit-parit di Lampung Barat dominan merupakan bentukan alam sedangkan parit-parit di DAS Way Sekampung beberapa merupakan parit buatan. Diduga keberadaan parit alami dan buatan merupakan bentuk adaptasi dengan topografi lingkungan tempat hidup yang berbeda yaitu di dataran tinggi dan dataran rendah. Selain sebagai bentuk adaptasi, perilaku membuat parit keliling juga di jumpai di Thailand. Hal tersebut memunculkan dugaan adanya kaitan wilayah Lampung sebagai wilayah sebaran penutur Austronesia jalur barat yang juga melalui wilayah Thailand khususnya jalur barat yang dapat diverifikasi lebih lanjut.

\section{DAFTAR PUSTAKA}

Agus, Yondri, L., \& Saptono, N. (1995). Laporan Hasil Penelitian Lingkungan dan Tinggalan Arkeologis di Situs Klasik Hara Kuning, Kabupaten Lampung Barat. Propinsi Lampung. Bandung.

Anwar Herryzal. (1994). Proceeding Ekspose Ilmiah Puslitbang Geoteknologi LIPI. Karakteristik Enjinering Lapisan Tufa Pasiran Dan Tanah Residu Di Daerah Liwa Dan Sekitarnya, 1-9. Puslitbang Geoteknologi LIPI.

Bellier, O., Bellon, H., Sébrier, M., Sutanto, \& Maury, R. C. (1999). K-Ar age of the Ranau Tuffs: Implications for the Ranau caldera emplacement and slippartitioning in Sumatra (Indonesia). Tectonophysics, 312(2-4), 347-359.
https://doi.org/10.1016/S00401951(99)00198-5

Bemmelen, R. W. van. (1949). The Geology of Indonesia Vol.IA. The Hague Netherlands: Martinus Nyhoff.

Boyd, W. E., Higham, C. F. W., \& McGrath, R. J. (1999). The Geoarchaeology of Iron Age"Moated" Sites of the Upper Mae NamMun Valley, N.E. Thailand. I:Palaeodrainage, Site- LandscapeRelationships and the Origins of the "Moats." Geoarchaeology An International Journal, 14(7), 675-716.

D.W.Burbank, R. . A. (2012). Tectonic Geomorphology. UK: WileyBlackwell.

Damais, L. C. (1995). Epigrafi dan Sejarah Nusantara Pilihan Karangan LouisCharles Damais. Jakarta: Pusat Penelitian dan Dokumentasi EFEO Jakarta.

Dougald J.W, O., \& Scott, G. (2015). Moated sites of the Iron Age in the Mun River Valley, Thailand: New discoveries using Google Earth. ELSEVIER: Archaeological Research in Asia, 3(JUly), 9-18. https://doi.org/https:// doi.org/10.1016/j.ara.2015.06.001

Endang Widyastuti. (2010). Kondisi Masyarakat Lampung Pada Masa Pengaruh hindu-Buddha. In W. R. Wahyudi (Ed.), Dari Masa Lalu ke Masa Kini: Kajian Budaya Materi, Tradisi, dan Pariwisata (pp. 17-26). Bandung: Alqa Print Jatinangor.

Endang Widyastuti. (2011). Masa Penghunian dan Pemanfaatan Situs Tanjung Raya Lampung. In S. Rahardjo (Ed.), Arkeologi: Pola Permukiman dan Lingkungan Hidup. Bandung: Alqa Print Jatinangor.

Laili, N. (2007). Permukiman Benteng Majapahit, Lampung Utara. In S. Rahardjo (Ed.), Permukiman, 
Lingkungan, dan Masyarakat (pp. 81-89). Bandung: Ikatan Ahli Arkeologi Indonesia (IAAI) Komda Jabar Banten.

Laili, N. (2008). Permukiman Bertradisi Megalitik di Situs Serampang, Rawa Sragi, Lampung. In K. Yulianto (Ed.), Dinamika Permukiman dalam Budaya Indonesia (pp. 31-44). Bandung: Ikatan Ahli Arkeologi Indonesia (IAAI) Komda Jabar Banten.

Nurul Laili, Anton Ferdianto, Unggul Prasetyo Wibowo, Amir, Y. Hardikusmana, Desril Riva Shanti, Dede Sumiyati, M. A. (2019). Sebaran Spasial Situssitus neolitik di DAS Cibeureum Kabupaten Lebak Bukti Sebaran Penutur Austronesia. Bandung.

R.r. Triwurjani. (2010). Adaptasi Komunitas Megalitik di DAS Sekampung Provinsi Lampung. In E. S. Hardiati \& R. r. Triwurjani (Eds.), Pentas Ilmu di Ranah Budaya: Sembilan Windu Prof.Dr. Edi Sedyawati (p. 575). Jakarta: Pustaka Larasan.

Rusyanti. (2012). Keruangan Situs Tanjung Raya Lampung Barat. In H. O. Untoro (Ed.), Arkeologi Ruang: Lintas Waktu sejak Prasejarah hingga Kolonial di Situs-situs Jawa Barat dan Lampung (pp. 143-158). Bandung: Alqa Print Jatinangor.

Rusyanti. (2014). Permukiman Kuno di Sekitar Situs Tanjung Raya dan Hujung Langit Kecamatan Sukau Kabupaten Lampung Barat. Laporan Penelitian. Bandung.

Rusyanti, Laili, N., Hardikusmana, Y., \& Amir. (2012). Permukiman Klasik di Situs Tanjung Raya Kecamatan Sukau Kabupaten Lampung Barat. Laporan Penelitian. Bandung.

Rusyanti, Purwoarminta, A., Krama, A. ., \& Widyastuti, E. (2018). Lansekap Arkeologi Situs-situs di DAS Way
Semangka Lampung Barat. Laporan Penelitian. Bandung.

Saptono, N. (2000). Pola dan Perkembangan Permukiman di Sepanjang Way Tulangbawang. In E. Saringendyanti (Ed.), Kronik Arkeologi: Perspektif Hasil Penelitian Arkeologi di Jawa Barat, Kalimantan Barat, dan Lampung (pp. 144-166). Jakarta: Pusat Penelitian Arkeologi Nasional.

Sarjiyanto. (2007). Model Perkampungan Situs Tepi Sungai di Lampung Tengah: Sebuah Hipotesis. In Permukiman, Lingkungan, dan Masyarakat (pp. 1-16).

Sieh, K., \& Natawidjaja, D. (2000). Neotectonics of the Sumatran fault, Indonesia. Journal of Geophysical Research, 105(B12), 28295. https:// doi.org/10.1029/2000JB900120

Simanjuntak, T. (2017). The Western Route Migration: A Second Probable Neolithic Diffusion to Indonesia. In et. al Philip J. Piper (Ed.), New Perspectives in Southeast Asian and Pacific Prehistory (pp. 201-2011). Canberra: Australian National University Press.

\section{HASIL DISKUSI}

\section{Pertanyaan}

\section{Eko Punto Hendro}

Apakah mungkin parit-parit tersebut memiliki makna simbolik?

\section{Budianto Hakim}

Di Sulawesi menemukan parit yang berkonteks dengan benteng pertahanan. Berdasarkan tokoh masyarakat dalam penelitian di sana, parit memiliki dua fungsi meliputi pengairan dan tempat persembunyian ketika terdesak. 
Mungkin bisa juga dilihat situs berparit di Benteng Cenrana, Kabupaten Bone Sulawesi Selatan barangkali mempunyai kemiripan?

\section{Nanang Saptono}

Paleochannel yang ada di Thailand itu, apakah seperti danau tapal kuda (oxbow lake?) kalo seperti itu, di Tulangbawang sepertinya banyak

\section{Jawaban}

1. Belum tau karena ini baru identifikasi awal. Parit dapat juga bermakna simbolik jika terlihat adanya keteraturan dan pola yang selaras dengan dogma atau konsep religinya, seperti misalnya konsep mikro dan makro kosmos pada
Hindu-Buddha akan tetapi jikapun demikian, pemaknaan juga perlu memperhatikan sumber sekunder dan sumber lainnya yang mendukung untuk memboboti sudut pandang teori mengenai pemaknaan yang akan digunakan nantinya

2. Jika situs tersebut berasal dari masa Islam dapat juga dilihat sebagai perbandingan mengingat konteks masa parit di Lampung ini juga masih belum jelas, kapan dibuatnya sedangkan data kronologi relatif yang ada hingga saat ini permukiman berparit memiliki rentang kronologi yang panjang sejak $10-19 \mathrm{M}$

3. Informasi yang menarik. Perlu penelitian geoarkeologi untuk mengkonfirmasinya. 


\title{
"KUE" DARI SITUS GUNUNG SUSURU SEBAGAI JEJAK TEKNOLOGI MASA BERCOCOK TANAM
}

\author{
“Kue” from Susuru Mountain Site as a Trace Technology in the Farming Period
}

\author{
Endang Widyastuti, Nanang Saptono, Rusyanti \\ Balai Arkeologi Jawa Barat \\ Jalan Raya Cinunuk Km.17 Cileunyi, Bandung \\ E-mail: endangwidyastuti6@gmail.com
}

\begin{abstract}
Austronesian culture is a culture that is supported by a group of people initially settling in a particular region who then travel to various other regions in a very wide range of areas. In the Indonesian Archipelago contact with the Austronesian culture had occurred during farming. The form of culture in the technological aspects includes pottery technology and bark processing. In a study conducted in Mount Susuru in the Kertabumi region, artifacts made from terracotta with unique shapes and decorations were found. Terracotta is found in a number and variety of shapes and decorations quite a lot. Local people refer to the artifact as "kue". Based on the comparison of forms through literature studies, this paper aims to determine the relationship of the "kue" with pottery technology and bark processing.
\end{abstract}

Keywords: "kue”, Mount Susuru, earthenware, bark processing.

\begin{abstract}
Abstrak
Kebudayaan Austronesia merupakan budaya yang didukung oleh sekelompok orang awalnya menetap di suatu wilayah tertentu yang kemudian melakukan perjalanan ke berbagai wilayah lainnya dalam rentang area yang sangat luas. Di Kepulauan Indonesia kontak dengan budaya austronesia telah terjadi pada masa bercocok tanam. Bentuk budaya tersebut dalam aspek teknologi diantaranya menyangkut teknologi gerabah dan pengolahan kulit kayu. Dalam penelitian yang pernah dilakukan di Gunung Susuru kawasan Kertabumi, ditemukan artefak berbahan terakota dengan bentuk yang unik dan terdapat beragam goresan di permukaannya. Terakota tersebut ditemukan dalam jumlah dan variasi bentuk serta hiasan yang cukup banyak. Masyarakat setempat menyebut artefak tersebut sebagai "kue". Berdasarkan perbandingan bentuk melalui studi pustaka, tulisan ini bertujuan untuk mengetahui kaitan "kue" tersebut dengan teknologi gerabah dan pengolahan kulit kayu.
\end{abstract}

Kata kunci: "kue”, Gunung Susuru, gerabah, pengolahan kulit kayu.

\section{PENDAHULUAN}

$\mathrm{K}$ emampuan membuat gerabah merupakan salah satu lompatan yang besar pada budaya manusia. Kemampuan membuat gerabah mulai muncul pada masa bercocok tanam. Berbicara mengenai kemampuan membuat gerabah tidak dapat dilepaskan dengan keberadaan rumpun bangsa Austronesia. Bangsa Austronesia telah bermigrasi ke seluruh pelosok dunia hingga dapat ditemukan di hampir separo belahan dunia. Mengenai perpindahan Bangsa Austronesia ini beberapa ahli telah memaparkan pendapatnya tentang asal usul dan jalur perpindahannya (Noerwidi, 2014, hal. 2). Dalam bermigrasi mereka 